\title{
Recovery of metals from waste nickel-metal hydride batteries using multifunctional Diphonix resin
}

\author{
D. Fila ${ }^{1} \cdot$ Z. Hubicki $^{1}$ - D. Kołodyńska ${ }^{1}$
}

Received: 18 November 2018 / Revised: 11 January 2019 / Accepted: 14 January 2019 / Published online: 25 January 2019

(c) The Author(s) 2019

\begin{abstract}
In this study, Diphonix resin containing sulfonic, diphosphonic and carboxylic groups was used to evaluate the adsorption capacity of metal ions contained in the nickel-metal hydride batteries (Ni-MH). This type of ion exchanger can be considered as the multifunctional material having great affinity to many metal ions. Using Diphonix resin adsorption process was carried out for $\mathrm{La}(\mathrm{III})$ and $\mathrm{Ni}(\mathrm{II})$ ions to characterize kinetic, adsorption and thermodynamic parameters. Preliminary studies of the $\mathrm{Nd}(\mathrm{III}), \mathrm{Ce}(\mathrm{III}), \mathrm{La}(\mathrm{III}), \mathrm{Fe}(\mathrm{III}), \mathrm{Co}(\mathrm{II}), \mathrm{Ni}(\mathrm{II}), \mathrm{Cu}(\mathrm{II})$ and $\mathrm{Zn}$ (II) metal ions mixture were also performed. The best results of adsorption studies were obtained using $0.2 \mathrm{M} \mathrm{HNO}_{3}$. Diphonix resin exhibits especially good adsorptive properties with respect to rare earth element ions (adsorption efficiency of about 100\%) in comparison with the heavy metal ions in the second oxidation state (about 50\% or below). The series of affinity of the resin for the studied ions can be presented as follows: $\mathrm{La}(\mathrm{III})>\mathrm{Fe}(\mathrm{III})>\mathrm{Nd}(\mathrm{III})>\mathrm{Ce}(\mathrm{III})>\mathrm{Cu}(\mathrm{II})>\mathrm{Zn}(\mathrm{II})>\mathrm{Co}(\mathrm{II})>\mathrm{Ni}(\mathrm{II})$. The obtained results confirmed the possibility of further use of the resin for the recovery and separation of rare earth elements from solutions after Ni-MH batteries leaching.
\end{abstract}

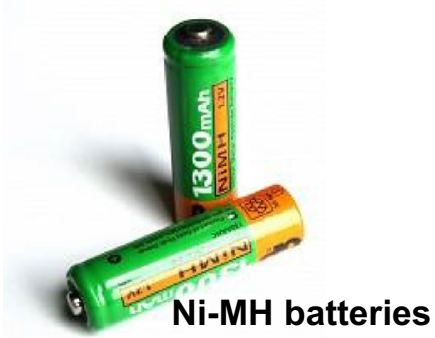

Batteries leaching

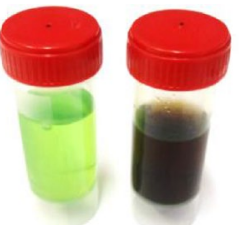

REEs and heavy metal ions solution
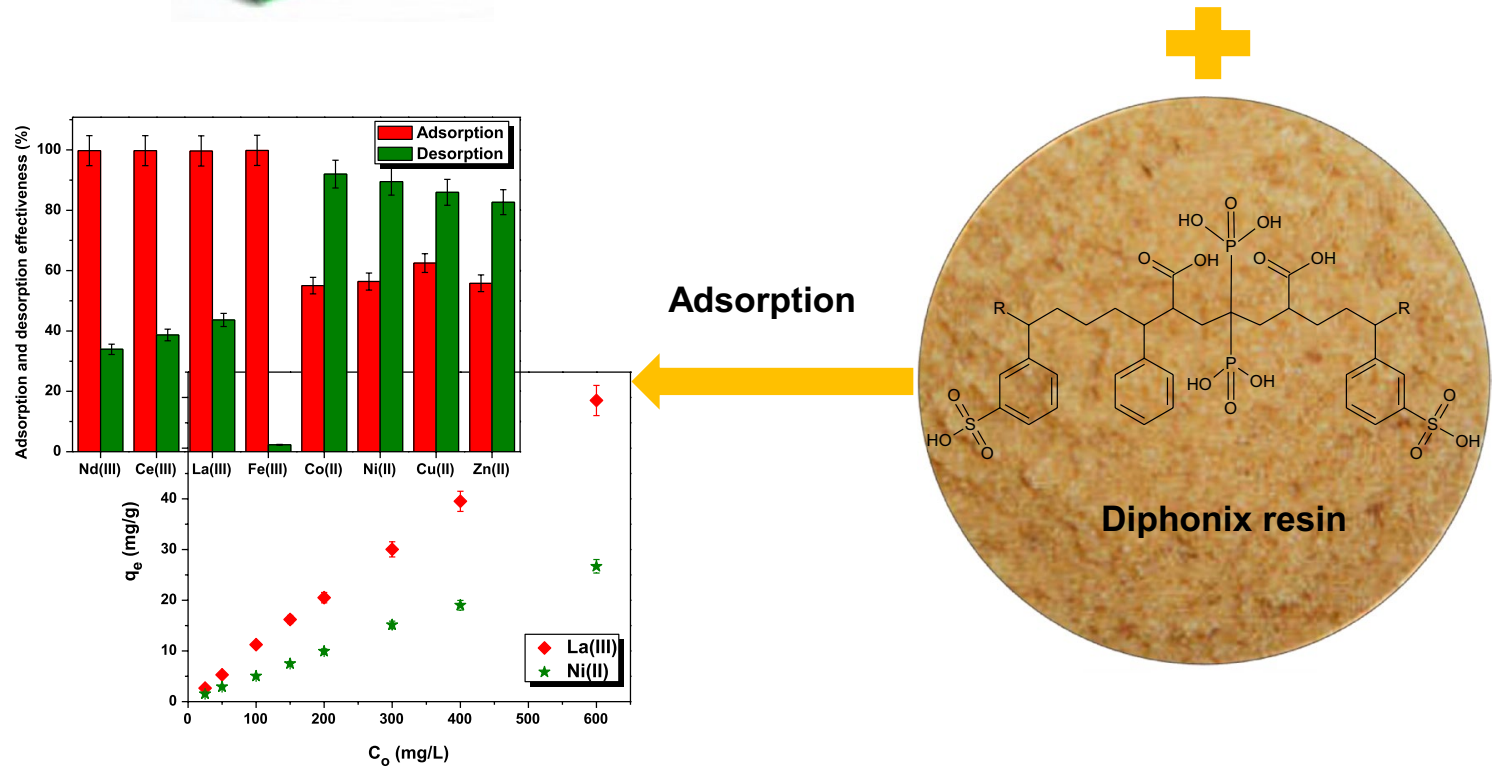

Extended author information available on the last page of the article 
Keywords Diphonix resin $\cdot$ Metal ions recovery $\cdot$ Affinity $\cdot$ Adsorption $\cdot$ Batteries

\section{Introduction}

Nowadays development of technology as well as production of various portable electrical devices results in creation of large amounts of wastes (Bertuol et al. 2009; Müller and Friedrich 2006; Pietrelli et al. 2005; Skowroński et al. 2015). Moreover, all European Union countries are obliged to undertake the actions ensuring a selective collection and recycling of spent galvanic cells including commonly known as batteries or accumulators. Such activities follow some legal regulations (among others, the previous-93/86/ EEC, 98/101/EC, 2006/66/WE PE and Council and present 2012/19/UE about batteries and accumulators as well as their wastes). The spent batteries impose serious threat for the natural environment as they contain many dangerous substances, among others, heavy metals (HM). On the other hand, they constitute a source of valuable metals including rare earth elements (REEs). Therefore of significant importance is suitable recycling of such materials which is based not only on elimination of threat as a result of harmful elements content but also on recovery of valuable metals as a secondary raw material (Ekberg and Petranikova 2015; Müller and Friedrich 2006; Pietrelli et al. 2005, 2002).

As for commercial cells the most common are zinc-carbon batteries, disposable alkaline batteries, lithium and nickel-cadmium batteries, nickel-metal hydride or acid-lead accumulators. Of them nickel-metal hydride (Ni-MH) cells, commonly called accumulators become more and more common as they are believed to be one of more important sources of energy for various types of mobile applications, storage of stationary energy and also transport. More and more frequently they replace toxic nickel-cadmium (Ni-Cd) cells, are capable of acting in a wide range of temperatures and possess a sealed system limiting electrolyte leaks and minimizing conservation problems (Kwo-Hsiung et al. 2016; Kwo-Hsiung 2016; Meshram et al. 2015; Rodrigues and Mansur 2010; Santos et al. 2012; Tarabay and Karami 2015). The cathode of the Ni-MH cell is the porous polymer impregnated with "paste" containing active nickel compounds $\mathrm{Ni}(\mathrm{OH})_{2}$ as well as other additives stabilizing the electrode and improving its conductivity. Anode, similarly to the cathode, is composed of porous polymer impregnated with the mixture of metal ions both the rare earth and heavy metals (HMs), among others, $\mathrm{Nd}, \mathrm{Ce}, \mathrm{La}, \mathrm{Pr}$ and $\mathrm{Fe}, \mathrm{Co}$, $\mathrm{Ni}, \mathrm{Cu}, \mathrm{Zn}, \mathrm{Al}$, capable of hydride formation. The active anode material are hydrogen ions which during charging and discharging of the battery are absorbed and desorbed by the above mentioned metals. The electrodes are separated from each other by a synthetic porous membrane which enables the contact of electrolyte ( $\mathrm{KOH}$ solution) contained in electrode space with both electrodes (Bertuol et al. 2006; Pietrelli et al. 2005; Rodrigues and Mansur 2010; Santos et al. 2012; Tarabay and Karami 2015; Young 2016). The electrode charging and discharging processes in cell can be written as: (Lucas et al. 2015; Shengqiang et al. 2015):

$\mathrm{M}+\mathrm{Ni}(\mathrm{OH})_{2} \stackrel{\text { charge }}{\longrightarrow} \mathrm{MH}+\mathrm{NiOOH}$

$\mathrm{MH}+\mathrm{NiOOH} \stackrel{\text { discharge }}{\longrightarrow} \mathrm{M}+\mathrm{Ni}(\mathrm{OH})_{2}$

where $\mathrm{M}$ means hydrogen storage alloys while $\mathrm{MH}$ means metal hydride.

Therefore the nickel-metal hydride (Ni-MH) cells are one of the most frequently selected and used batteries in everyday life. They provide not only high performance but they are also a source of valuable metals, such as REEs. Rare earth elements are widely applied in many industrial branches (aviation, motorization, power engineering, lighting etc.) and high-tech applications (Chakhmouradian and Wall 2012; Meshram et al. 2016; Pietrelli et al. 2002). Lately China supply of REEs has been over 90\%. In 2010 it stopped the export of these precious elements and increased their prices. Therefore an important issue is independence of REEs export from China and looking for new methods of obtaining them from other sources (Meshram et al. 2016, 2017).

Considering the fact that every year billions of spent nickel-metal hydride cells get on the consumer market, their proper management is indispensable. Their recycling can result in the double advantage as regards environmental protection and obtaining high purity valuable metals. The common methods of metals recovery from the spent $\mathrm{Ni}-\mathrm{MH}$ cells include pyrometallurgical or hydrometallurgical ones. Under suitable conditions and stages of the process the hydrometallurgical method allows for selective removal or separation of metals with simultaneous minimization of by-products. Moreover, these methods are preferred for economic reasons (Jha et al. 2016; Meshram et al. 2016, 2015; Müller and Friedrich 2006; Pietrelli et al. 2002; Santos et al. 2012; Skowroński et al. 2015; Wang et al. 2012).

Pyrometallurgical methods consist in the recovery of materials by their melting in special furnaces. Their advantage is the possibility of recycling cells of various types, including those containing organic electrolytes. In turn, the relatively low efficiency of such recycling and the possibility of secondary waste generation during the process significantly limit their use. On the other hand, the hydrometallurgical processes consist in acid or alkaline leaching of properly prepared battery wastes (after machining processes). 
This is followed by a series of physicochemical operations that lead to the separation and concentration of valuable components between the respective phases, up to the commercial and semi-finished products for different technological processes. The advantage of these methods is low energy expenditure and the formation of a small amount of secondary wastes. The total process usually includes the following stages: dissolving the appropriate waste fractions, purification and concentration of the resulting solution and separation of pure chemical compounds. Among advantages should be listed the following: the possibility of effective recovery of metals and high purity compounds from multi-component raw materials with low and variable concentrations of elements, low energy consumption and the process temperatures (below $373 \mathrm{~K}$ ), the process does not require expensive reagents and complicated equipment, the possibility of solutions reuse, decrease of the emission of harmful products into the environment, recovery of high purity metals for the use in small industrial plants installation, reduction of the amount of stored materials hazardous for the environment and implementation of EU development policy (Innocenzi et al. 2017; Shengqiang et al. 2015). In this method the ion exchange with specific resins can be applied. Among them, the Diphonix resin requires special attention (Alexandratos 2007). It was proposed for Iron Control Process developed by Eichrom Industries in order to remove of $\mathrm{Fe}$ (III) during hydrometallurgical processing of $\mathrm{Cu}(\mathrm{II}), \mathrm{Zn}(\mathrm{II}), \mathrm{Ni}(\mathrm{II})$ and Co(II) (Gula and Dreisinger 1996; Xue et al. 2001). It was proved that for the $\mathrm{Fe}_{2}\left(\mathrm{SO}_{4}\right)_{3} \cdot 5 \mathrm{H}_{2} \mathrm{O}$ solution in $3 \mathrm{~N} \mathrm{H}_{2} \mathrm{SO}_{4}$ after $2 \mathrm{~h}$ of contact, iron(III) uptake was $40 \%$ i.e., higher than for Duolite C-467 with the aminophosphonic group. Analogous results were obtained for Diphonix by McKevitt and Dreisinger (McKevitt and Dreisinger 2009). Therefore the above-mentioned resin was applied for Fe(III) removal from spent copper electrolyte in FENIX Iron Control System, Australia (Shaw et al. 2004). Moreover, Diphonix can strongly sorb actinides, especially in the IV and VI oxidation states from highly acidic (up to $10 \mathrm{M} \mathrm{HNO}_{3}$ ) and highly salted solutions as well as transition and post-transition metals in the presence of alkali and alkaline earth metal ions i.e., $\mathrm{Na}(\mathrm{I})$ and $\mathrm{K}(\mathrm{I})$ as well as $\mathrm{Ca}(\mathrm{II})$ and $\mathrm{Mg}$ (II) (Chiariza et al. 1997). As for the alkaline earth metal ions sorption does not depend on the size of hydrated cations according the Gregor's theory but it is mainly due to chelation by the diphosphonic groups. For $0.1 \mathrm{M} \mathrm{HNO}_{3}$ the affinity series is as follows: $\mathrm{Fe}(\mathrm{III})>>\mathrm{Ca}(\mathrm{II})=\mathrm{Cr}(\mathrm{III})>\mathrm{Zn}(\mathrm{II})>\mathrm{Ag}(\mathrm{I})>\mathrm{C}$ $\mathrm{o}(\mathrm{II})>>\mathrm{Sb}(\mathrm{V})>\mathrm{Hg}(\mathrm{II})$ and for $5 \mathrm{M} \mathrm{HNO}_{3} \mathrm{Fe}(\mathrm{III})>\mathrm{Cr}$ (II I) $>\mathrm{Ag}(\mathrm{I})>\mathrm{Sb}(\mathrm{V})>\mathrm{Co}(\mathrm{II})=\mathrm{Zn}$ (II) $=\mathrm{Hg}$ (II) $>\mathrm{Ca}$ (II) (Horwitz et al. 1993). It can also be used for removal of U(VI) and such hazardous metal ions as $\mathrm{V}(\mathrm{V}), \mathrm{Cr}(\mathrm{VI}), \mathrm{Mn}(\mathrm{IV})$, $\mathrm{Co}(\mathrm{II}), \mathrm{Ni}(\mathrm{II}), \mathrm{Zn}$ (II), $\mathrm{Cd}(\mathrm{II}), \mathrm{Hg}$ (II) and $\mathrm{Pb}$ (II) from waters and wastewaters as well as $\mathrm{Mn}(\mathrm{II}), \mathrm{Co}(\mathrm{II})$ and $\mathrm{Ni}$ (II) from oil refinery process waters generated in being washed catalysts used for desulfurization processes and $\mathrm{Fe}(\mathrm{III})$ removal in the boiler descaling operations (Phillips et al. 2008). Based on the distribution coefficients $\mathrm{Zn}$ (II), $\mathrm{Cu}$ (II) and $\mathrm{Zn}$ (II) ions are sorbed through the ion exchange reaction. It is also possible to sorb $\mathrm{TcO}_{4}{ }^{-}$in the form of $\mathrm{HTcO}_{4}$ by hydrogen bonding to the phosphoryl groups. As well for the actinides D as high as $10^{8}$ for $\mathrm{Am}$ from $0.1 \mathrm{M} \mathrm{HCl}$ and $10^{6}$ to $10^{7}$ for $\mathrm{Pu}(\mathrm{IV})$, $\mathrm{Th}(\mathrm{IV})$ and $\mathrm{U}(\mathrm{VI})$ up to $1 \mathrm{M} \mathrm{HCl}$ were found (Horwitz et al. 1997b). Moreover, Diphonix can be used for interferences such as $\mathrm{U}, \mathrm{Pu}, \mathrm{Th}, \mathrm{Nb}, \mathrm{V}, \mathrm{Mo}, \mathrm{Zr}, \mathrm{W}, \mathrm{Fe}, \mathrm{Cr}, \mathrm{Ce}, \mathrm{Er}$ and Ti removal during Be determination (Maxwell III et al. 2008). Additionally, it can be used for effective separation of $\mathrm{Zr}$ and $\mathrm{Hf}$ and metal ions in the presence of the biodegradable complexing agents with EDDS and GLDA (Kołodyńska 2010; Smolik et al. 2009).

Diphonix resin is widely used in the removal and recovery of metal ions from various solutions even at very acidic ones. It binds different metal ions forming chelate complexes with the phosphoryl groups of the diphosphonic groups. The mechanism of metal ions sorption on different oxidation states $\left(\mathrm{M}^{\mathrm{n}+}\right)$ onto Diphonix resin can be presented as (Chiarizia et al. 1994; Hajiev et al. 1989):

$\mathrm{R}-\left(\mathrm{PO}_{3} \mathrm{H}_{2}\right)_{2}^{2-}+\mathrm{M}^{\mathrm{n}+} \rightleftarrows \mathrm{R}-\left(\mathrm{PO}_{3} \mathrm{H}_{2}\right)_{2}^{2-} \rightarrow \mathrm{M}^{\mathrm{n}+}$

where $\mathrm{R}$ is the Diphonix resin matrix.

The aim of the paper was to study possibilities of recovery of metal ions contained in the Ni-MH cells through their adsorption on the commercially available Diphonix resin. The first stage of the research was the evaluation of the adsorption capacity of the Diphonix towards two metal ions $\mathrm{La}(\mathrm{III})$ and $\mathrm{Ni}$ (II) and the optimization of adsorption process. Desorption efficiency of the above mentioned metal ions was also examined. In the second stage preliminary studies of the adsorption process from the model solutions containing a metal ions mixture with different initial concentrations corresponding to the average content of metal ions in solution after leaching of spent Ni-MH cells was conducted. These studies can contribute to possibility of the further use of this resin for metal ions removal from real solutions after leaching of spent Ni-MH cells.

\section{Materials and Methods}

\subsection{Resin}

For the adsorption studies, the Diphonix resin was applied. This material is a commercially available multifunctional chelating resin supplied by Eichrom Industries. It was developed by the members of the Separation Chemistry Group of the Chemistry Division of Argonne National Laboratory and the University of Tennessee, Department of Chemistry. 
The name Diphonix is the acronym for diphosphonic ion exchanger (Horwitz et al. 1993). It is characterized by a strong affinity for Fe(III) over the mono- and divalent metal ions. The main physicochemical properties of Diphonix are presented in Table 1. In contrast to other ion exchangers with multifunctional groups, the geminally substituted diphosphonic as well as carboxylic groups of Diphonix are not attached to the phenyl ring within the polymer matrix. This provides high hydrophilicity for kinetics of metal species (measures by the water regain). Moreover, the sulfonic functional groups are utilized to improve exchange kinetics. The performance of Diphonix can be analogous to the vinylidene-1,1-diphosphonic acid (VDPA). The protonation constants of Diphonix resin which are $p K_{1}$ and $p K_{2}<2.5$ $p K_{3}=7.24$ and $p K_{4}=10.46$ appear to be almost equal to the protonation constants of the starting material VDPA and are $p K_{1}=1.27, p K_{2}=2.41, p K_{3}=6.67$ and $p K_{4}=10.04$ (Chiariza et al. 1997; Nash et al. 1994). This provides the possibility of strong complexes formation under acidic conditions by forming coordination bonds with metal ions through phosphoryl oxygen. The crosslinking (the content of divinylbenzene) of the resin exchangers is about $10 \%$ DVB. The total capacity is $5.4 \mathrm{meq} / \mathrm{g}$ assuming two acidic protons from each phosphonate and one per sulfonate. According to Nash et al. (1994) the sulfonate functional groups are randomly distributed on the benzene rings.

In order to remove any residual contamination originating from the resin synthesis, prior to the experiments it was contacted with $1 \mathrm{M} \mathrm{NaOH}$ and $\mathrm{HCl}$ solutions. After that the resin was washed with distilled water. The operation was

Table 1 Physicochemical characteristics of the Diphonix resin (Chiariza et al. 1997; Kołodyńska 2010)

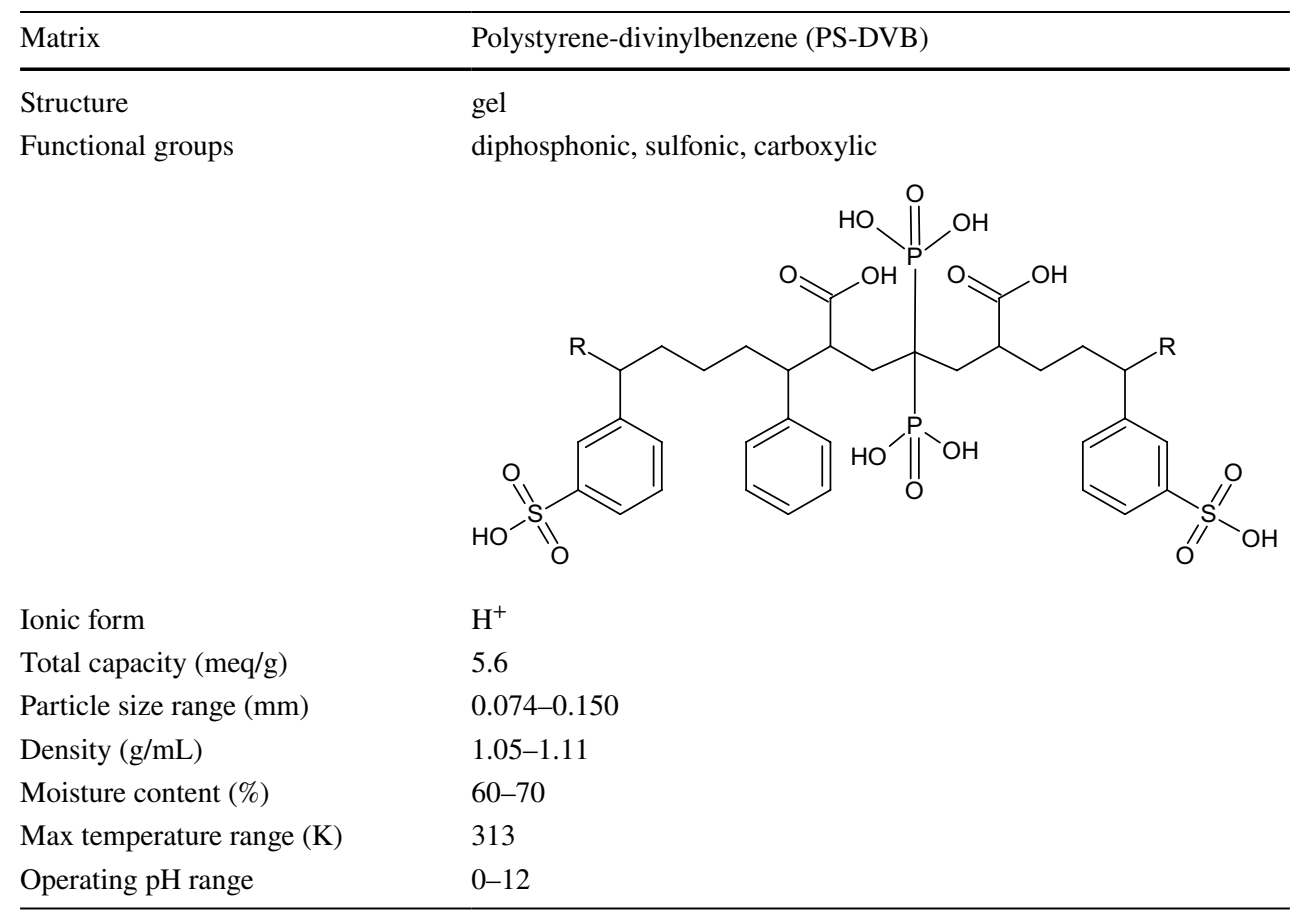

repeated several times and then the resin was allowed to dry at room temperature.

\subsection{Reagents and solutions}

The model solutions of single metal ions $\mathrm{Ni}(\mathrm{II})$ and $\mathrm{La}(\mathrm{III})$ as well as the mixture of metal ions i.e., $\mathrm{Nd}(\mathrm{III}), \mathrm{Ce}(\mathrm{III})$, $\mathrm{La}(\mathrm{III}), \mathrm{Fe}(\mathrm{III}), \mathrm{Co}(\mathrm{II}), \mathrm{Ni}(\mathrm{II}), \mathrm{Cu}(\mathrm{II}), \mathrm{Zn}$ (II) at different initial concentrations were used in adsorption studies. The qualitative and quantitative compositions of the solutions were selected based on that of the real solution after leaching of Ni-MH cells with nitric acid. All experiments were performed using nitric acid concentration at the concentration $0.2 \mathrm{M}$.

The stock solution of $\mathrm{La}(\mathrm{III})$ with a concentration of $1000 \mathrm{mg} / \mathrm{L}$ was prepared using lanthanum(III) oxide $\left(\mathrm{La}_{2} \mathrm{O}_{3}\right.$, Specpure, JMC, England). This oxide was initially heated in the FB Thermo Scientific Series oven (USA) at $1173 \mathrm{~K}$ for $4 \mathrm{~h}$. After this time, the sample was put into the exsiccator to cool. Next, an appropriate amount of the oxide was weighed and taken up with a solution of nitric acid. At first, the oxide was treated with $1 \mathrm{M} \mathrm{HNO}_{3}$ solution and then several drops of the concentrated acid solution was added for complete $\mathrm{La}_{2} \mathrm{O}_{3}$ dissolution. The solutions were quantitatively transferred to conical flasks and supplemented with the $0.2 \mathrm{M}$ $\mathrm{HNO}_{3}$ solution. The stock solution of $\mathrm{Ni}(\mathrm{II})$ with a concentration of $1000 \mathrm{mg} / \mathrm{L}$ was prepared by dissolving a suitable amount of $\mathrm{Ni}\left(\mathrm{NO}_{3}\right)_{2} \cdot 6 \mathrm{H}_{2} \mathrm{O}$ salt (Avantor Performance Materials Poland S.A.) in the $0.2 \mathrm{M} \mathrm{HNO}_{3}$ solution. The solutions of lower concentrations were prepared by appropriate 
dilution of the $\mathrm{La}(\mathrm{III})$ and $\mathrm{Ni}(\mathrm{II})$ stock solutions using nitric acid solution at the concentration $0.2 \mathrm{M}$.

The stock solution of mixture metal ions was prepared in such a way that the metal ions concentrations corresponded to the average real concentrations in the leaching solution i.e., $91 \mathrm{mg} / \mathrm{L}$ of $\mathrm{Nd}(\mathrm{III}), 129 \mathrm{mg} / \mathrm{L} \mathrm{Ce}(\mathrm{III}), 712 \mathrm{mg} / \mathrm{L} \mathrm{La}(\mathrm{III})$, $1175 \mathrm{mg} / \mathrm{L} \mathrm{Fe}(\mathrm{III}), 326 \mathrm{mg} / \mathrm{L} \mathrm{Co}(\mathrm{II}), 2688 \mathrm{mg} / \mathrm{L} \mathrm{Ni}(\mathrm{II})$, $94 \mathrm{mg} / \mathrm{L} \mathrm{Cu}$ (II) and $90 \mathrm{mg} / \mathrm{L} \mathrm{Zn(II).} \mathrm{The} \mathrm{solutions} \mathrm{of} \mathrm{Nd(III)}$ was prepared from $\mathrm{Nd}_{2} \mathrm{O}_{3}$ in the same way as shown above. The following metal salts (at appropriate amount) were used to prepare the remaining solutions: $\mathrm{Ce}\left(\mathrm{NO}_{3}\right)_{3} \cdot 6 \mathrm{H}_{2} \mathrm{O}$ (POCh S.A., Poland), $\mathrm{Fe}\left(\mathrm{NO}_{3}\right)_{3} \cdot 9 \mathrm{H}_{2} \mathrm{O}, \mathrm{Co}\left(\mathrm{NO}_{3}\right)_{2} \cdot 6 \mathrm{H}_{2} \mathrm{O}$, $\mathrm{Ni}\left(\mathrm{NO}_{3}\right)_{2} \cdot 6 \mathrm{H}_{2} \mathrm{O}, \mathrm{Cu}\left(\mathrm{NO}_{3}\right)_{2} \cdot 3 \mathrm{H}_{2} \mathrm{O}$ and $\mathrm{Zn}\left(\mathrm{NO}_{3}\right)_{2} \cdot 6 \mathrm{H}_{2} \mathrm{O}$ (Avantor Performance Materials Poland S.A.). The mixture of metal ions was completed with the $0.2 \mathrm{M} \mathrm{HNO}_{3}$ solution.

\subsection{Apparatus}

The laboratory shakers Elpin + type 357 (water bath shaker) and Elpin + type 358A (Poland) were used for experiments. A PHM 82 laboratory pH-meter (Radiometer, Copenhagen) was used for measuring the $\mathrm{pH}$ values.

The metal ions concentrations were determined by an inductively coupled plasma optical emission spectrometer (ICP-OES, 720 ES, Varian). The wavelengths used for the analysis of $\mathrm{Nd}(\mathrm{III}), \mathrm{Ce}$ (III), $\mathrm{La}$ (III), $\mathrm{Fe}$ (III), $\mathrm{Co}$ (II), $\mathrm{Ni}$ (II), $\mathrm{Cu}$ (II) and $\mathrm{Zn}$ (II) were 401.224, 446.021, 333.749, 259.940, 238.892, 216.555, 327.395 and $206.200 \mathrm{~nm}$, respectively. The ICP-OES instrument was calibrated using the ICP standards for all analysed metal ions. For the preparation of all standards and blank samples, the ultrapure nitric acid was used to avoid any matrix interference.

The surface morphology of the Diphonix resin was studied using scanning electron microscopy (SEM) and atomic force microscopy (AFM). The SEM images were made using the Quanta 3D FEG instrument (FEI Company) and the AFM analysis was performed by using the NanoScope V microscope from Veeco (USA). The MULTIZOOM AZ 100M optical microscope (Nikon, Japan) was also used for the resin Diphonix surface analysis and obtaining an image with the extended depth of field (the EDF image). The parameters of porous Diphonix resin structure were determined measuring the adsorption/desorption isotherms of nitrogen at $77 \mathrm{~K}$. To this end the ASAP 2420 instrument from Micromeritics Instrument Corporation (USA) was used. Before measurements the samples were degassed at $343 \mathrm{~K}$. The surface area and pore size distribution (volume and pore diameter) were determined by means of the Brunauer-Emmett-Teller (BET) and the Barrett-Joyner-Halenda (BJH) methods, respectively.

A point of zero charge $\left(\mathrm{pH}_{\mathrm{pzc}}\right)$ of the Diphonix was determined using the potentiometric titration method for the three ionic strengths $(0.1,0.01$ and $0.001 \mathrm{M} \mathrm{NaCl})$. The suspensions of the resin $(0.3 \mathrm{~g})$ and $\mathrm{NaCl}$ solution $(30 \mathrm{~mL})$ were mixed using a magnetic stirrer and titrated with the standard solutions ( $0.1 \mathrm{M} \mathrm{HCl}$ and $0.1 \mathrm{M} \mathrm{NaOH})$. To this end the Dosino and Titrando kit (Metrohm) was used. The $\mathrm{pH}_{\mathrm{pzc}}$ of Diphonix was also determined using the drift method. For this purpose, $0.3 \mathrm{~g}$ of the resin and $30 \mathrm{~mL}$ of the $\mathrm{pH}-$ adjusted $0.01 \mathrm{M} \mathrm{NaCl}$ solution was added into a flask and stirred for $24 \mathrm{~h}$. The initial $\mathrm{pH}$ of solution was in the range of 2-12. After stirring, the solution was separated from the resin beads by filtration and then $\mathrm{pH}$ solutions $\left(\mathrm{pH}_{1}\right)$ were measured. At the end, the dependence of $\mathrm{pH}_{1}-\mathrm{pH}_{0}$ from $\mathrm{pH}_{0}$ was plotted on the graph. The point of intersection with the $\mathrm{x}$ axis gives the $\mathrm{pH}_{\mathrm{pzc}}$ value.

The water content in the resin Diphonix was also determined. The high-end titrator for volumetric and coulometric Karl Fischer titration equipped with the 807 Dosino dosing unit and the stove (Titrando, Metrohm) was used. The resin was previously dried in a laboratory dryer at $378 \mathrm{~K}$ to get rid of moisture and the representative sample of $0.1 \mathrm{~g}$ was selected for further water determination.

The Fourier transform infrared (FTIR) spectroscopy including an attenuated total reflectance (ATR) sampling module (Model Cary 630, Agilent Technologies, USA) was used to record the FTIR spectra of the Diphonix. After the spectrum measurement the baseline and ATR corrections were applied.

\subsection{Adsorption studies}

In order to assess the adsorption capacity of Diphonix resin in relation to metal ions and to optimize process conditions, the effects of the following conditions: $\mathrm{HNO}_{3}$ concentration, phase contact time, initial metal ions concentration and temperature were investigated. The adsorption process using a static method, at the constant ratio of the solution volume to the resin mass (100:1) and the constant shaking conditions (180 rpm, amplitude 8) was conducted.

In the first stage, the effect of $\mathrm{HNO}_{3}(0.2,0.5,1,1.5$ and $2 \mathrm{M}$ ) on the adsorption of $\mathrm{La}(\mathrm{III})$ and $\mathrm{Ni}$ (II) ions was studied. The adsorption process was performed at room temperature, at the initial metal ions concentration equal to $50 \mathrm{mg} / \mathrm{L}$ and phase contact time equal to $120 \mathrm{~min}$. Next, the effect of phase contact time was examined from 1 to $120 \mathrm{~min}$. The initial $\mathrm{La}$ (III) and $\mathrm{Ni}$ (II) ions concentration was equal to $50 \mathrm{mg} / \mathrm{L}$. The effect of the initial concentrations from 25 to $600 \mathrm{mg} / \mathrm{L}$ was also determined. The influence of temperature in the range from 293 to $313 \mathrm{~K}$ on the $\mathrm{La}(\mathrm{III})$ and $\mathrm{Ni}(\mathrm{II})$ ions adsorption efficiency was evaluated. The studies were carried out at the initial metal ions concentration of $50 \mathrm{mg} / \mathrm{L}$ and for time equal to $120 \mathrm{~min}$.

In the second stage, the adsorption kinetics of the mixture metal ions on the Diphonix was examined. The stock solution was diluted 20-fold and the efficiency of the adsorption 
process was determined by shaking a suitable amount of the resin and solution under the following conditions: phase contact time from 1 to $120 \mathrm{~min}$, room temperature and $0.2 \mathrm{M}$ $\mathrm{HNO}_{3}$ solution.

The resin affinity towards the above metal ions contained in the mixture was also estimated. For this purpose the distribution coefficient (D) was determined. Adsorption process was conducted under the following conditions: initial metal ions concentration equal to $50 \mathrm{mg} / \mathrm{L}, 0.2 \mathrm{M} \mathrm{HNO}_{3}$ solution, time shaking equal to $120 \mathrm{~min}$.

After the predetermined time, the all solutions were filtered using a $0.45 \mu \mathrm{m}$ pore size filter. The solutions $\mathrm{pH}$ was measured and the metal ion content was analysed. The resin aliquots were allowed to dry at room temperature for further desorption studies. The all studies were performed in three replicates, therefore, the results obtained were averaged. The measurement precision in each series was within 5\%.

\subsection{Desorption studies}

Desorption studies were carried out using the $0.5,1$ and $2 \mathrm{M}$ $\mathrm{HNO}_{3}$ solutions as eluting agents. The desorption process of $\mathrm{Ni}(\mathrm{II})$ and $\mathrm{La}(\mathrm{III})$ ions (initial concentration $50 \mathrm{mg} / \mathrm{L}$ ) as well as the mixture of metal ions from the Diphonix resin was performed. The $0.1 \mathrm{~g}$ dried and loaded resin and $10 \mathrm{~cm}^{3}$ of eluent solution were shaken in the Erlenmeyer flasks, stirring at $180 \mathrm{rpm}$ for $120 \mathrm{~min}$ at room temperature. The final concentrations of metal ions after the desorption process were determined.

\subsection{Data analysis}

\subsubsection{Basic parameters characterizing adsorption process}

Based on the adsorption studies such parameters as the amount of adsorbed metal ions at time $t\left(q_{t}\right)$, adsorption capacity $\left(q_{e}\right)$, adsorption effectiveness $(\% S)$ as well as the distribution coefficient $(D)$ were determined. The values of these parameters were calculated using the following equations:

$q_{t}=\left(C_{0}-C_{t}\right) V / m$

$q_{e}=\left(C_{0}-C_{e}\right) V / m$

$\% S=\left(\left(C_{0}-C_{t}\right) / C_{t}\right) \times 100 \%$

$D=\left(\left(C_{0}-C_{e}\right) / C_{e}\right) \times(V / m)$

where $C_{0}$ is the initial concentration of metal ions $(\mathrm{mg} / \mathrm{L})$, $C_{e}, C_{t}$ are the concentrations of metal ions at equilibrium and at time $t(\mathrm{mg} / \mathrm{L})$, respectively, $V$ is the solution volume (L) and $m$ is the resin mass (g).

The desorption efficiency of metal ions $(\% D)$ was also evaluated using the following equation:
$\% D=100 \% \times\left(C_{d e s} / C_{o}\right)$

where $C_{d e s}$ is the concentration of metal ions in the aqueous phase after desorption $(\mathrm{mg} / \mathrm{L})$ and $C_{0}$ is the initial concentration of metal ions $(\mathrm{mg} / \mathrm{L})$.

\subsubsection{Kinetic studies}

During adsorption from the liquid phase, the mass transport takes place in two main stages which are: external diffusion from the liquid to the surface of adsorbent beads and internal diffusion inside the adsorbent beads. The identification of the mechanism limiting the rate of the process is made the reaction kinetics behaviour. In order to evaluate the mechanism of the metal ions adsorption process on the Diphonix and to interpret the experimental data, several known kinetic models were used: the pseudo-first order (PFO), pseudosecond order (PSO), intraparticle diffusion (IPD) and Boyd models presented by following equations, respectively (Kiruba et al. 2014; Yuanfeng et al. 2016).

$\log \left(q_{e}-q_{t}\right)=\log \left(q_{e}\right)-k_{1} t / 2.303$

$t / q_{t}=\left(1 / k_{2} q_{e}^{2}\right)+\left(t / q_{e}\right)$

$q_{t}=k_{i} t^{1 / 2}+C_{i}$

$F=1-\left(6 / \pi^{2}\right) \exp (-B t)$

$B t=-0.4977-\ln (1-F)$

where $q_{e}$ and $q_{t}$ are the adsorbed metal ions amounts at equilibrium and at time $t(\mathrm{mg} / \mathrm{g})$, respectively, $t$ is the phase contact time ( $\mathrm{min}$ ), $k_{l}$ is the PFO equilibrium rate constant (1/ $\mathrm{min}), k_{2}$ is the PSO equilibrium rate constant $(\mathrm{g} /(\mathrm{mg} \mathrm{min})$ ), $k_{i}$ is the IPD rate constant $\left(\mathrm{mg} /\left(\mathrm{g} \mathrm{min}^{1 / 2}\right)\right), C_{i}$ is the IPD constant related to the boundary layer thickness, $F$ is the metal ion adsorbed fraction at time $t, B t$ is the $F$ mathematical function.

\subsubsection{Equilibrium studies}

The equilibrium isotherms analysis is useful for description of adsorbate ions behaviour during the adsorption process. The information about the affinity of the adsorbate ions for the resin and the interactions way at equilibrium can be obtained analyzing the equilibrium isotherm data. In order to describe the adsorption equilibrium data of metal ions adsorption onto the Diphonix, three adsorption isotherm models were used: Langmuir, Freundlich and Temkin models (Arthy and Saravanakumar 2013; Babaeivelni et al. 2014; Khalil et al. 2016):

$1 / q_{e}=\left(1 / q_{m} K_{L} C_{e}\right)+\left(1 / q_{m}\right)$

$\log q_{e}=\log K_{F}+\left((1 / n) \log C_{e}\right)$

$q_{e}=\ln \left(K_{T} C_{e}\right) R T / A_{T}$ 
where $q_{e}$ is the adsorption capacity $(\mathrm{mg} / \mathrm{g}), q_{m}$ is the maximum monolayer adsorption capacity $(\mathrm{mg} / \mathrm{g}), K_{L}$ is the Langmuir constant related to the adsorption energy $(\mathrm{L} / \mathrm{mg}), C_{e}$ is the metal ions concentration at equilibrium $(\mathrm{mg} / \mathrm{L}), K_{F}$ is the multilayer adsorption capacity $\left((\mathrm{mg} / \mathrm{g})(\mathrm{L} / \mathrm{mg})^{1 / \mathrm{n}}\right), 1 / n$ is the Freundlich constant related to the surface heterogeneity and the adsorption favourability, $R$ is the gas constant $(8.314 \mathrm{~kJ} /$ $\mathrm{mol} \mathrm{K}), T$ is the temperature (K), $A_{T}$ is the Temkin constant related to the adsorption heat $(\mathrm{J} / \mathrm{mol}), K_{T}$ is the Temkin constant related to the maximum binding energy $(\mathrm{L} / \mathrm{g})$.

\subsubsection{Thermodynamic studies}

In order to evaluate the nature of the adsorption process, the thermodynamic parameters like the enthalpy change $\left(\Delta H^{\circ}\right)$, the entropy change $\left(\Delta S^{\circ}\right)$ and the Gibbs free energy change $\left(\Delta G^{\circ}\right)$ were determined. Among them, the $\Delta G^{\circ}$ is the fundamental parameter for evaluation of adsorption process spontaneity. The value of the $\Delta G^{\circ}$ was obtained using the following equation:

$\Delta G^{\circ}=-R T \ln K_{c}$

$K_{c}=q_{e} / C_{e}$

where $K_{c}$ is the thermodynamic equilibrium constant.

The other thermodynamic parameters were estimated using the van't Hoff equation:

$\ln K_{c}=\Delta S^{\circ} / R-\Delta H^{\circ} / R T$

Plotting $\ln K_{c}$ against $1 / T$ the values of $\Delta S^{\circ}$ and $\Delta H^{\circ}$ as the intercept and the slope of the plot can be obtained (Yuanfeng et al. 2016).
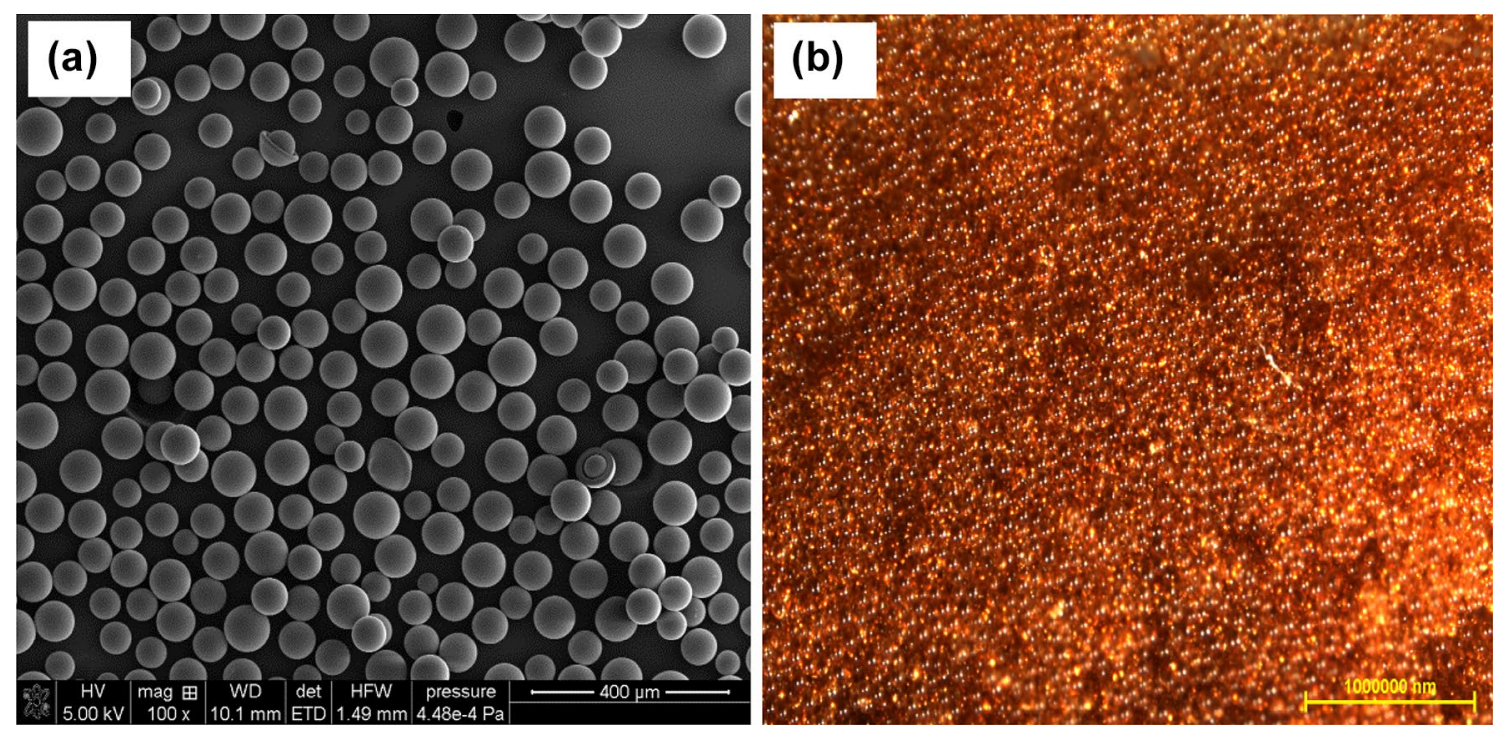

\section{Results and discussion}

\subsection{Resin characteristics}

\subsubsection{SEM, EDF and AFM studies}

The morphology of Diphonix resin surface are studied by means of the SEM, EDF and AFM methods. Based on the SEM results (Fig. 1a) it can be concluded that the resin surface is homogeneous and the resin beads are spherical. Unfortunately, it is not possible to obtain the information about the porosity of the resin surfaces directly by generating SEM images of the resin. Because the interpretation of the resin image by the extended depth of field is difficult, to this end the software for the 3-D visualization of in-focus topography was applied. The idea is to merge a stack of micrographs taken at different focal positions (aligned along the optical axis) into a single, entirely focused composite image. Based on this method the results obtained by means of optical microscope are presented in Fig. 1b. The resin is yellow/brown. Due to the change of the colour of Diphonix (it acts as an indicator), the mechanism of the sorption can be established. The AFM analysis allowed to present the resin surface in the two-dimensional (2D) and threedimensional (3D) spaces which are shown in Fig. 2a, b, respectively. The AFM images showed that the resin surface morphology is rough and porous. The determined roughness of the resin was $0.26 \mathrm{~nm}$.

Fig. 1 a SEM and b EDF images of the Diphonix resin 


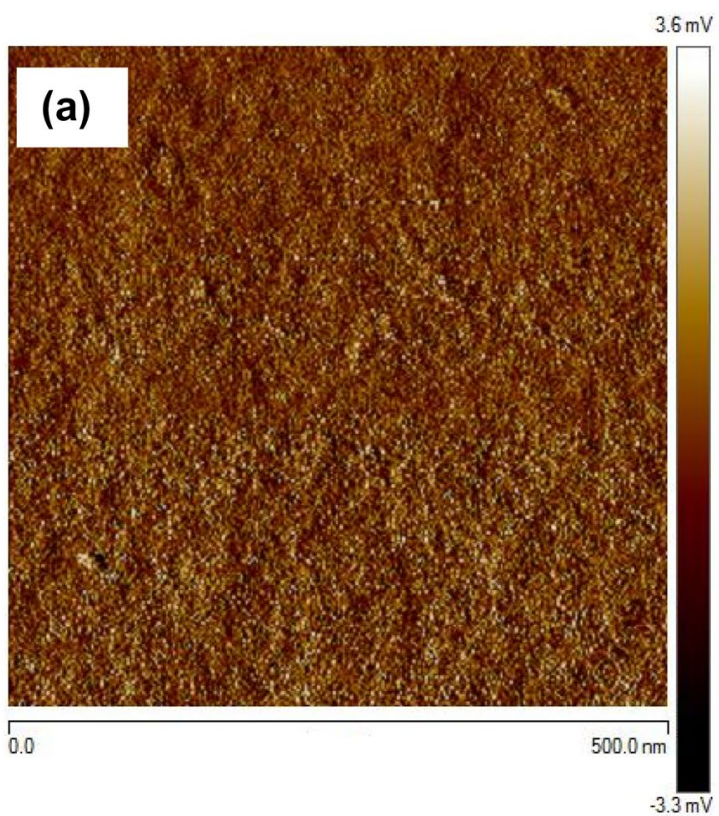

(b)

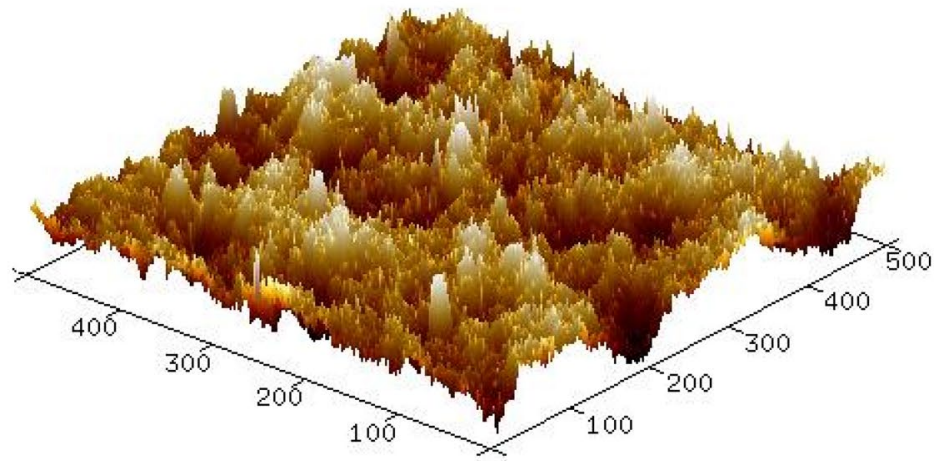

Fig. 2 2D (a) and 3D (b) AFM images of the Diphonix

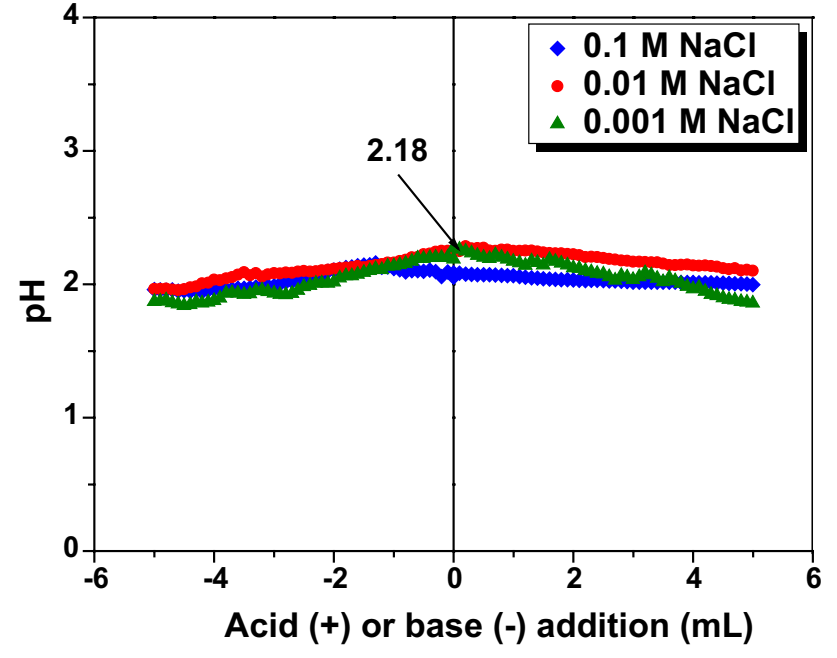

Fig. 3 The point of zero charge of the Diphonix determined by the potentiometric titration method

\subsubsection{ASAP studies}

Based on the analysis of nitrogen adsorption/desorption isotherm the pore and surface characteristics of the Diphonix were determined and the results were described below. A very low specific surface area of this material equals to $0.2 \mathrm{~m}^{2} / \mathrm{g}$ was obtained. This small value does not exclude this material as a potential adsorbent. In this case, the presence of many functional groups in its structure is more important, which allows it to be very efficiently binding with metal ions. The total pore volume and the BJH pore diameter of the non-loaded resin were $0.0003 \mathrm{~mL} / \mathrm{g}$ and $4.52 \mathrm{~nm}$, respectively. According to the IUPAC classification the average pore diameter is in the mesoporosity range $(2-50 \mathrm{~nm})$.

\subsection{3 $\mathrm{pH}_{\mathrm{pzc}}$ studies and water contents determination}

The point of zero charge $\left(\mathrm{pH}_{\mathrm{pzc}}\right)$ and the water content in the resin structure were also determined. The $\mathrm{pH}_{\mathrm{pzc}}$ of the Diphonix resin determined by the potentiometric titration method is presented in Fig. 3. The $\mathrm{pH}_{\mathrm{pzc}}$ value obtained using this method is 2.18 being close to that obtained by the drift method (1.85). Analysis of the water content by the Karl Fischer method showed that the resin sample contains $18.8 \%$ hydration water in its structure which was confirmed by the FTIR analysis.

\subsubsection{FTIR studies}

The Fourier transform infrared spectra of the resin Diphonix before and after $\mathrm{Ni}$ (II) and $\mathrm{La}$ (III) ions adsorption are shown in Fig. 4. They are very similar and contain different overlapping bands characteristic of the resin structure. A broad band in the $3600-3200 \mathrm{~cm}^{-1}$ region is characteristic of the $\mathrm{O}-\mathrm{H}$ groups of the acid and residual hydration water (Abderrahim et al. 2006; Lazar et al. 2014). The peaks at about $2926 \mathrm{~cm}^{-1}$ are due to the aliphatic $\mathrm{C}-\mathrm{H}$ stretching vibrations derived from the methyl groups in the main chain of resin. These bands are characteristic 


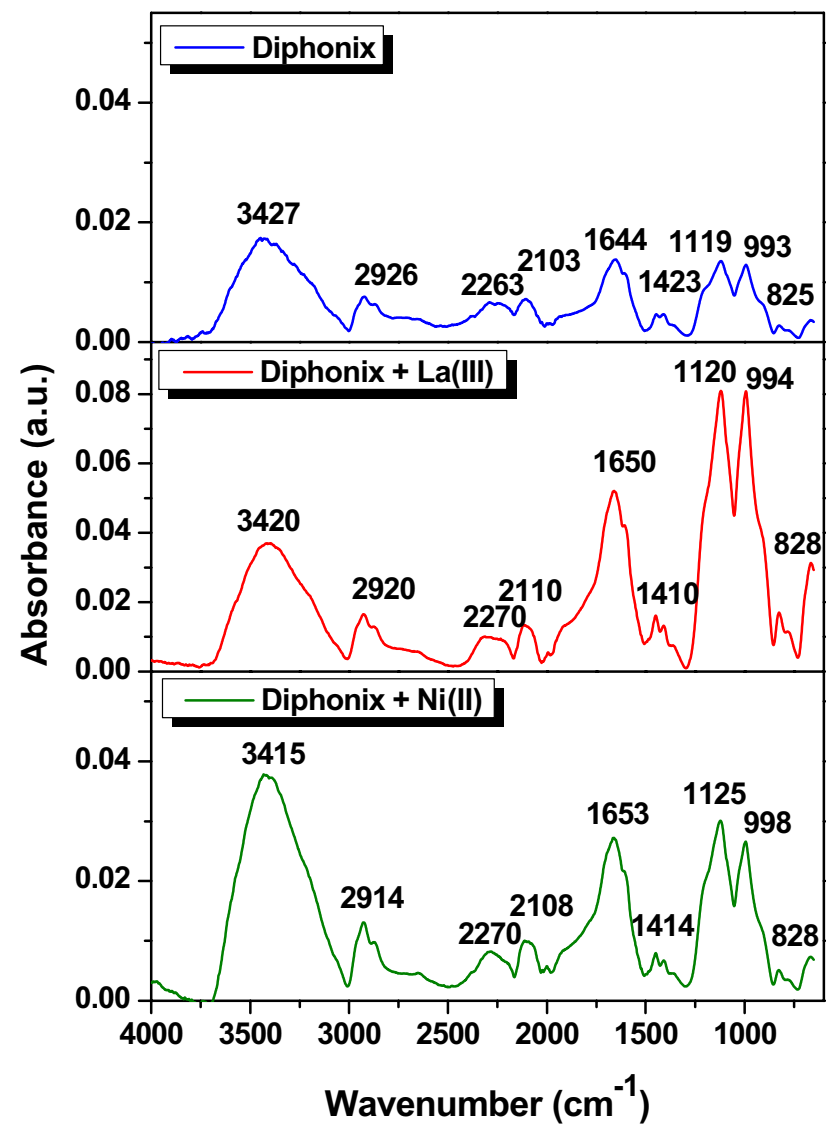

Fig. 4 FTIR spectra of the Diphonix before and after La(III) and $\mathrm{Ni}$ (II) ions adsorption

of the polystyrene structure (Lazar et al. 2014; Singare 2011). The bands at about 2263 and $2103 \mathrm{~cm}^{-1}$ can be attributed to the $\mathrm{O}-\mathrm{H}$ vibrations derived from the resin functional group. These are the bands of the stretching

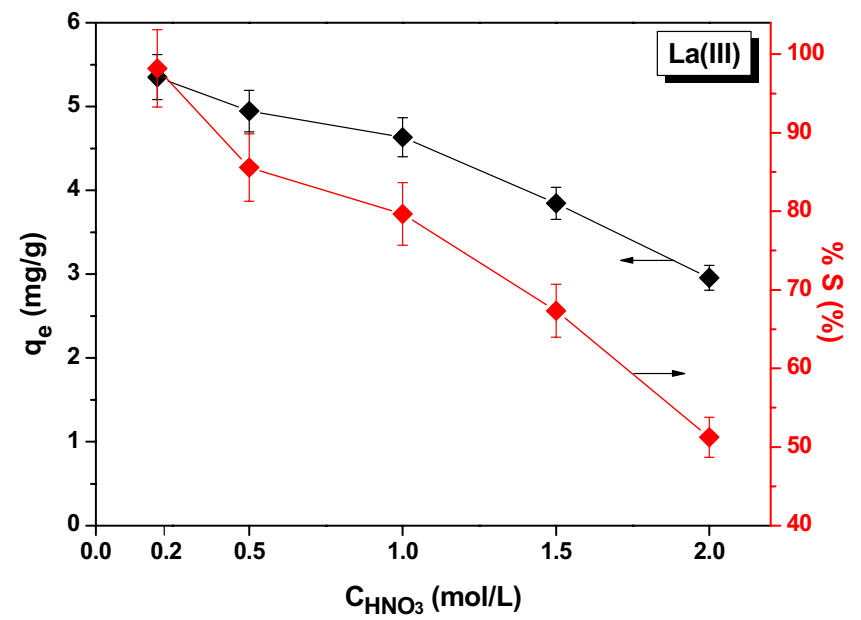

vibrations $(\nu(\mathrm{P}-\mathrm{OH}), \nu(\mathrm{S}-\mathrm{OH}))($ Abderrahim et al. 2006; Singare 2011). The band in the $1650-1550 \mathrm{~cm}^{-1}$ region is attributed to the presence of simple $\mathrm{C}=\mathrm{C}$ bonds in the styrene-divinylbenzene structure (Lazar et al. 2014). The peaks at $1423 \mathrm{~cm}^{-1}$ are assigned to the asymmetric deformation vibrations of $\mathrm{CH}_{2}$ groups in the resin structure. The absorption peaks at 1119 and $993 \mathrm{~cm}^{-1}$ correspond to the stretching symmetric and asymmetric vibrations of the sulfonic and phosphonic groups in the resin structure. The peak at $825 \mathrm{~cm}^{-1}$ is attributed to the $\mathrm{C}-\mathrm{H}$ out of plane deformation vibrations in the benzene ring. This band is associated with the crosslinking of divinylbenzene and the presence of sulfonic groups at the ring (Abderrahim et al. 2006; Lazar et al. 2014; Nekrasova et al. 2010). Additionally, the adsorption bands in the $1200-900 \mathrm{~cm}^{-1}$ region are attributed to the $\mathrm{S}=\mathrm{O}$ stretching vibrations in sulfonate and $\mathrm{P}=\mathrm{O}$ stretching vibrations in the phosphonate functional groups e.g. $1119,993,821 \mathrm{~cm}^{-1}$. Especially in the range $1000-800 \mathrm{~cm}^{-1}$ the asymmetric and symmetric vibrations of the $\mathrm{P}(\mathrm{OH})$ groups are located. For the Diphonix resin and Diphonix-Ni(II) the bands are quite similar being located at 993 and $994 \mathrm{~cm}^{-1}$. However, for Diphonix$\mathrm{La}$ (III) it is located at $998 \mathrm{~cm}^{-1}$ (Alexandratos and Zhu 2018; Chiarizia et al. 1995).

\subsection{Effect of $\mathrm{HNO}_{3}$ concentration}

On the beginning in adsorption tests the effect of $\mathrm{HNO}_{3}$ concentration on $\mathrm{La}(\mathrm{III})$ and $\mathrm{Ni}$ (II) ions adsorption capacity on Diphonix resin was studied. The results are illustrated in Fig. 5. A decrease in adsorption capacity of the resin $\left(q_{e}\right)$ relative to the metal ions with the increasing $\mathrm{HNO}_{3}$ concentration was observed. Metal ions adsorption is much lower using $2 \mathrm{M} \mathrm{HNO}_{3}$ than $0.2 \mathrm{M} \mathrm{HNO}_{3}$ indicating a strong competition for the active sites of the studied ions than for

Fig. 5 Effect of $\mathrm{HNO}_{3}$ concentration on the $\mathrm{La}(\mathrm{III})$ and $\mathrm{Ni}(\mathrm{II})$ ions adsorption on the Diphonix 


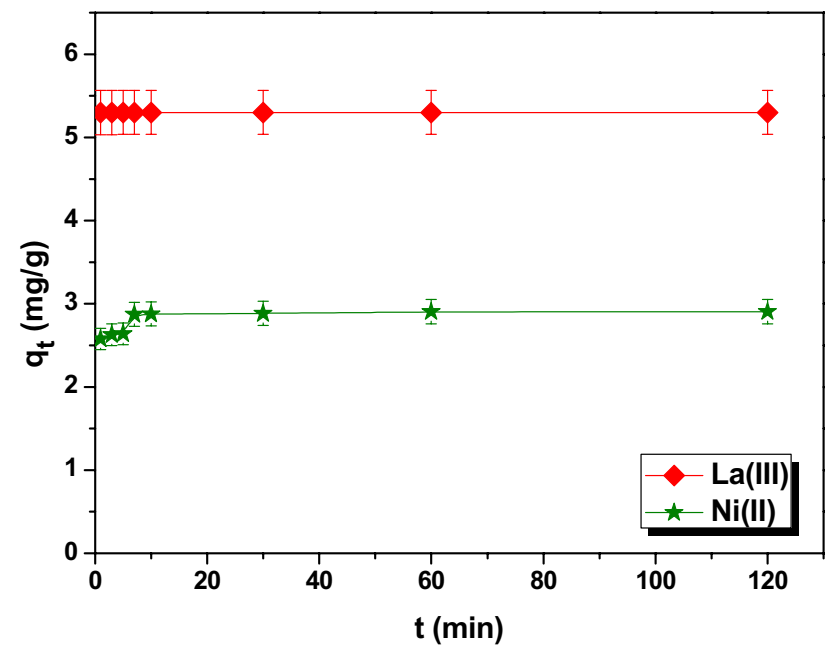

Fig. 6 Effect of phase contact time on the adsorbed amount of $\mathrm{La}(\mathrm{III})$ and $\mathrm{Ni}(\mathrm{II})$ ions on the Diphonix

hydronium ions. Better adsorption results with $\mathrm{La}(\mathrm{III})$ ions were obtained which indicates that the resin has a greater selectivity towards rare earth ions than towards $\mathrm{Ni}(\mathrm{II})$ ions. Metal ions with a higher charge are more strongly bound by the resin functional groups.

\subsection{Effect of phase contact time and kinetic studies}

Figure 6 presents the dependence of phase contact time on the amount of adsorbed metal ions $\left(q_{t}\right)$. It can be seen that in the case of $\mathrm{La}$ (III) ions equilibrium is established almost immediately which suggests a very strong affinity of ions for the resin. In the case of $\mathrm{Ni}$ (II) ions, the equilibrium is achieved a little later after about $10 \mathrm{~min}$.
Based on the effect of phase contact time the reaction kinetics was determined. For this purpose, different kinetic models were used. The PFO and PSO models were applied to determination of kinetic parameters. However, they are not useful for describing a more detailed mechanism of the metal ions adsorption process. For this purpose the IPD and Boyd models were applied. A linear regression of the models was used to determine kinetic parameters. The obtained values for the PFO, PSO, IPD and Boyd models are listed in Table 2.

The experimental data was compared with that determined from the kinetic models. For this purpose the coefficient of determination, $R^{2}$ was used. The $R^{2}$ value equal to unity indicates the $\mathrm{La}(\mathrm{III})$ and $\mathrm{Ni}$ (II) ions adsorption process proceeds according to the second order kinetics. The value of the constant rate, $k_{2}$, determined for the PSO model, decreases with the increase of the concentration of the metal ions solution, which means that the increase in

Table 3 Comparison of adsorbed amounts of $\mathrm{La}(\mathrm{III})$ and $\mathrm{Ni}(\mathrm{II})$ ions on Diphonix resin depending on the metal ion concentration

\begin{tabular}{lcr}
\hline Concentration $(\mathrm{mg} / \mathrm{L})$ & \multicolumn{2}{l}{ Adsorbed amount $(\mathrm{mg} / \mathrm{g})$} \\
\cline { 2 - 3 } & \multicolumn{1}{l}{$\mathrm{La}(\mathrm{III})$} & $\mathrm{Ni}(\mathrm{II})$ \\
\hline 25 & $2.67 \pm 0.13$ & $1.54 \pm 0.08$ \\
50 & $5.30 \pm 0.27$ & $2.91 \pm 0.15$ \\
100 & $11.25 \pm 0.56$ & $5.03 \pm 0.25$ \\
150 & $16.20 \pm 0.81$ & $7.47 \pm 0.37$ \\
200 & $20.50 \pm 1.02$ & $9.91 \pm 0.49$ \\
300 & $30.03 \pm 1.50$ & $15.13 \pm 0.76$ \\
400 & $39.51 \pm 1.98$ & $19.01 \pm 0.95$ \\
600 & $59.41 \pm 2.97$ & $26.69 \pm 1.33$ \\
\hline
\end{tabular}

Table 2 Calculated parameters for the used kinetic models

\begin{tabular}{|c|c|c|c|c|c|c|c|}
\hline \multirow[t]{2}{*}{ Kinetic model } & \multirow[t]{2}{*}{ Parameter } & \multirow[b]{2}{*}{50} & \multicolumn{2}{|l|}{$\mathrm{La}(\mathrm{III})$} & \multicolumn{3}{|l|}{$\mathrm{Ni}(\mathrm{II})$} \\
\hline & & & 100 & 200 & 50 & 100 & 200 \\
\hline & $q_{\exp }(\mathrm{mg} / \mathrm{g})$ & 5.30 & 11.25 & 20.50 & 2.91 & 5.03 & 9.91 \\
\hline \multirow[t]{3}{*}{ Pseudo-first order } & $q_{1}(\mathrm{mg} / \mathrm{g})$ & 0.01 & 0.02 & 0.03 & 0.21 & 0.30 & 0.14 \\
\hline & $k_{1}(1 / \min )$ & 0.02 & 0.06 & 0.08 & 0.09 & 0.09 & 0.01 \\
\hline & $R^{2}$ & 0.452 & 0.855 & 0.993 & 0.849 & 0.979 & 0.404 \\
\hline \multirow[t]{3}{*}{ Pseudo-second order } & $q_{2}(\mathrm{mg} / \mathrm{g})$ & 5.30 & 11.25 & 20.50 & 2.91 & 5.04 & 9.91 \\
\hline & $k_{2}(\mathrm{~g} / \mathrm{mg} \min )$ & 20.11 & 17.30 & 10.75 & 1.43 & 1.08 & 0.88 \\
\hline & $R^{2}$ & 1.000 & 1.000 & 1.000 & 1.000 & 1.000 & 1.000 \\
\hline \multirow[t]{6}{*}{ Intraparticle diffusion } & $k_{\mathrm{i} 1}\left(\mathrm{mg} / \mathrm{g} \min ^{1 / 2}\right)$ & 0.01 & 0.01 & 0.01 & 0.16 & 0.03 & 0.14 \\
\hline & $C_{1}$ & 5.29 & 11.22 & 20.45 & 2.38 & 4.75 & 9.51 \\
\hline & $R^{2}$ & 0.906 & 0.952 & 0.840 & 0.802 & 0.848 & 0.841 \\
\hline & $k_{\mathrm{i} 2}\left(\mathrm{mg} / \mathrm{g} \min ^{1 / 2}\right)$ & - & - & - & 0.01 & 0.02 & 0.04 \\
\hline & $C_{2}$ & - & - & - & 2.87 & 4.83 & 9.76 \\
\hline & $R^{2}$ & - & - & - & 0.792 & 0.809 & 0.875 \\
\hline \multirow[t]{2}{*}{ Boyd } & $B t$ & 0.0070 & 0.0072 & 0.0079 & 0.0057 & 0.0059 & 0.0033 \\
\hline & $R^{2}$ & 0.849 & 0.979 & 0.805 & 0.842 & 0.855 & 0.994 \\
\hline
\end{tabular}




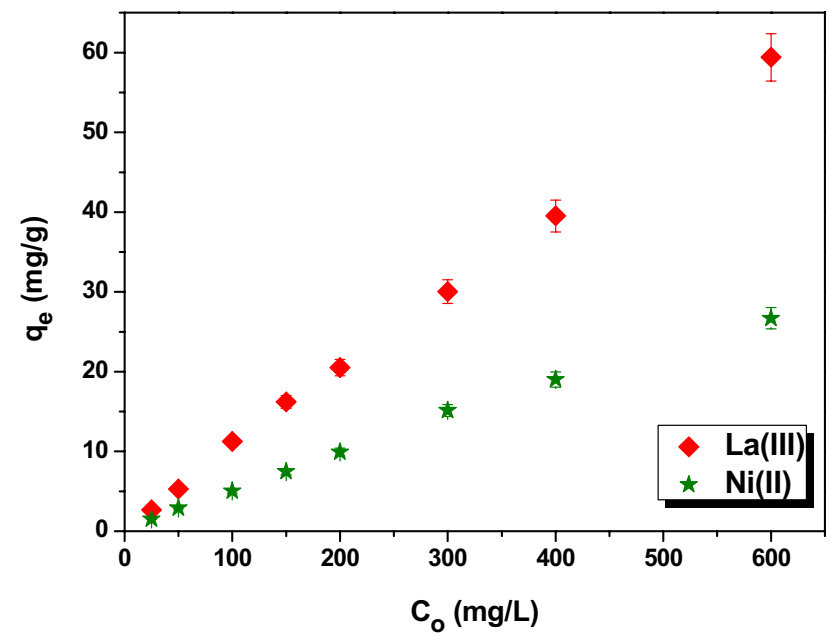

Fig. 7 Effect of initial solution concentration on the adsorbed amount of metals at equilibrium onto the Diphonix resin

concentration causes a decrease in the sorption process rate. For the solid-liquid adsorption process, it is important to determine the rate controlling step. There can be the following steps or their combination: a film diffusion i.e. diffusion of the adsorbate ions through the boundary layer or a pore diffusion i.e. diffusion of the adsorbate ions through the pores (Ali et al. 2016). Based on the IPD results it can be concluded that $\mathrm{Ni}$ (II) ions adsorption onto the resin takes place in two stages and La(III) ions adsorption occurs in one stage by surface adsorption. Based on the nonlinear Boyd plot it can be inferred that chemical reaction or film diffusion can be responsible for controlling the reaction rate (Arthy and Saravanakumar 2013; Khalil et al. 2016; Viegas et al. 2014).

\subsection{Effect of initial concentration and equilibrium studies}

Adsorption effectiveness is also depends on the initial metal concentration. On the basis of the data presented in Table 3

Table 4 Calculated adsorption parameters for the isotherm models

\begin{tabular}{llcc}
\hline Isotherm model & Parameter & $\mathrm{La}(\mathrm{III})$ & $\mathrm{Ni}(\mathrm{II})$ \\
\hline Langmuir & $q_{m}(\mathrm{mg} / \mathrm{g})$ & 98.73 & 45.75 \\
& $K_{L}(\mathrm{~L} / \mathrm{mg})$ & 0.88 & 0.01 \\
& $R^{2}$ & 0.989 & 0.945 \\
Freundlich & $K_{F}\left[(\mathrm{mg} / \mathrm{g})(\mathrm{L} / \mathrm{mg})^{1 / \mathrm{n}}\right]$ & 41.57 & 2.23 \\
& $1 / n$ & 0.76 & 0.71 \\
& $R^{2}$ & 0.989 & 0.996 \\
Temkin & $A_{T}(\mathrm{~J} / \mathrm{mol})$ & 16.27 & 7.17 \\
& $K_{T}(\mathrm{~L} / \mathrm{g})$ & 11.99 & 14.79 \\
& $R^{2}$ & 0.932 & 0.905 \\
\hline
\end{tabular}

and Fig. 7 it can be noticed that increasing the initial concentration influences the increase of adsorption capacity $\left(\mathrm{q}_{\mathrm{e}}\right)$ of the resin in relation to the tested metal ions. Due to the stronger affinity of $\mathrm{La}$ (III) ions for the resin as compared to the $\mathrm{Ni}$ (II) ions, nearly $100 \%$ adsorption efficiency of $\mathrm{La}$ (III) ions was obtained over the whole concentration range. The $\mathrm{Ni}(\mathrm{II})$ adsorption efficiency is in the range of about 50 to about $70 \%$ for the lowest and highest concentrations, respectively.

Based on the equilibrium results presented in Table 4, it can be concluded that the adsorption process follows the Freundlich isotherm. This is confirmed in the high value of the coefficient of determination, $R^{2}$. This points out that adsorption of $\mathrm{Ni}$ (II) and $\mathrm{La}(\mathrm{III})$ ions is not limited to the formation of monolayers. The relatively high $R^{2}$ values in the Temkin isotherm model indicate that the main mechanism of the adsorption process are the electrostatic interactions between the metal ions and the resin. The Langmuir constant, $K_{L}$ indicates the metal ions affinity for the Diphonix resin. Based on the values obtained for the Ni(II) and $\mathrm{La}(\mathrm{III})$ ions it can be specified that $\mathrm{La}$ (III) ions have a higher affinity for the resin than $\mathrm{Ni}(\mathrm{II})$ ions. The Freundlich parameter, $K_{F}$ points out to the binding force between the metal ions and the resin. For La(III) ions the $K_{F}$ value is much higher than for $\mathrm{Ni}(\mathrm{II})$ ions. As follows $\mathrm{La}(\mathrm{III})$ ions are more strongly bound with the resin surface than $\mathrm{Ni}$ (II) ions. The $1 / n$ parameter is responsible for surface heterogeneity or adsorption favourability. When $1 / n$ is smaller than 1 , the adsorption process is favourable and when it gets close to zero, the resin surface is more heterogeneous. The $1 / n$ values for $\mathrm{Ni}(\mathrm{II})$ and $\mathrm{La}(\mathrm{III})$ ions about 0.70 indicate that the adsorption process is favourable and that the resin surface is more homogeneous than heterogeneous (Khalil et al. 2016).

\subsection{Effect of temperature and thermodynamic studies}

When assessing the effect of temperature, it was noticed that its increase does not significantly affect the adsorption capacity of the resin in relation to the studied metal ions. In the case of $\mathrm{La}(\mathrm{III})$ ions, the adsorption capacity of the resin over the entire temperature range is $5.30 \mathrm{mg} / \mathrm{g}$. However, at $313 \mathrm{~K}$ the adsorption capacity of the resin in relation to

Table 5 Thermodynamic parameters of adsorption process

\begin{tabular}{llll}
\hline Parameter & & $\mathrm{La}(\mathrm{III})$ & $\mathrm{Ni}(\mathrm{II})$ \\
\hline$\Delta \mathrm{H}^{\circ}(\mathrm{kJ} / \mathrm{mol})$ & & -6.98 & -11.71 \\
$\Delta \mathrm{S}^{\circ}(\mathrm{J} / \mathrm{mol} \mathrm{K})$ & & 12.14 & -43.92 \\
$\Delta \mathrm{G}^{\circ}(\mathrm{kJ} / \mathrm{mol})$ & $293 \mathrm{~K}$ & -26.81 & -12.79 \\
& $303 \mathrm{~K}$ & -27.46 & -13.15 \\
& $313 \mathrm{~K}$ & -28.17 & -13.27 \\
\hline
\end{tabular}


$\mathrm{Ni}(\mathrm{II})$ ions is $3.17 \mathrm{mg} / \mathrm{g}$ and is only slightly higher than the value obtained at $303 \mathrm{~K}$ and $293 \mathrm{~K}$ (3.14 and $2.91 \mathrm{mg} / \mathrm{g}$, respectively).

Based on the influence of temperature on the metal ions adsorption the thermodynamics and adsorption process nature were also evaluated. The determined values of thermodynamic parameters are listed in Table 5. The negative enthalpy change value $\left(\Delta H^{\circ}\right)$ indicates the exothermic nature of the adsorption process of $\mathrm{La}$ (III) and $\mathrm{Ni}$ (II) ions. In addition, the value of $\Delta H^{\circ}$ below $40 \mathrm{~kJ} / \mathrm{mol}$ indicates the physical nature of adsorption, i.e., intermolecular forces are between the metal ions and the resin surface. The positive $\Delta S^{\circ}$ value suggests an increase in the adsorption of La(III) ions on the adsorbent surface, while a the negative value of the $\Delta S^{\circ}$ indicates a decrease in the randomness during the adsorption of $\mathrm{Ni}$ (II) ions. Furthermore, in both cases the process is spontaneous and thermodynamically favourable as indicated by the negative values of free Gibbs enthalpy, $\Delta G^{\circ}$ over the entire temperature range. The values of $\Delta G^{\circ}$, which are about $-20 \mathrm{~kJ} / \mathrm{mol}$ or higher can indicate the existence of both physical (electrostatic interactions) and chemical interactions (coordination bonds) during the adsorption of La(III) ions on the resin. Moreover, the values of $\Delta G^{\circ}$ in the range $-20-0 \mathrm{~kJ} / \mathrm{mol}$ or below indicate the electrostatic nature of the Ni(II) ions adsorption process which shows that physisorption contributes significantly to the adsorption process (Bentiss et al. 2005; Issaadi et al. 2011; Konicki et al. 2017; Reguyal et al. 2016).

\subsection{Distribution coefficient comparison for REE and $\mathrm{HM}$ ions}

The Diphonix affinity for metal ions was presented using the distribution coefficient, $D$, which is a mass-weighted partition coefficient between the liquid adsorbate phase and solid

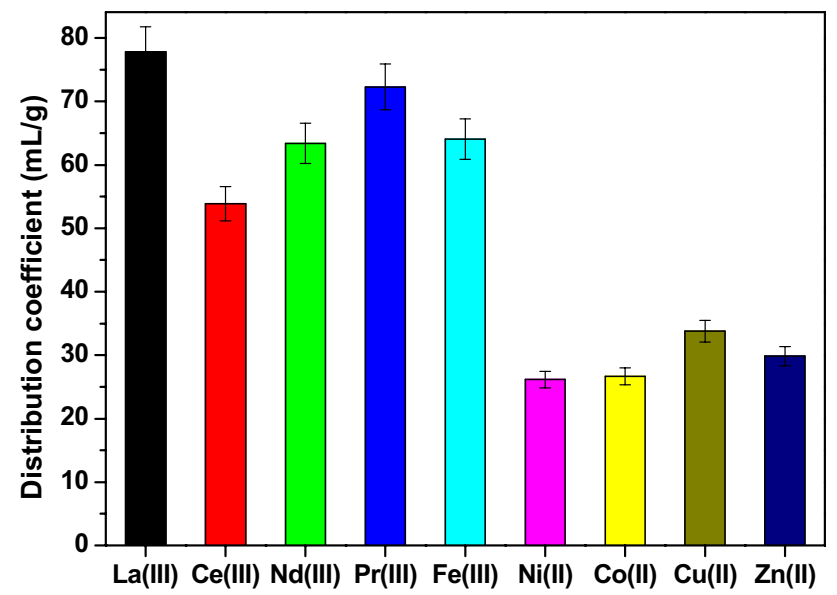

Fig. 8 Distribution coefficients for rare earth elements and heavy metal ions phase (Yantasee et al. 2009). Figure 8 presents the comparison of the distribution coefficients of rare earth elements i.e. $\mathrm{La}(\mathrm{III}), \mathrm{Ce}(\mathrm{III}), \operatorname{Pr}(\mathrm{III}), \mathrm{Nd}(\mathrm{III})$ and heavy metal ions Fe(III), $\mathrm{Ni}(\mathrm{II}), \mathrm{Co}(\mathrm{II}), \mathrm{Cu}(\mathrm{II})$ and $\mathrm{Zn}(\mathrm{II})$ as a main constituents of $\mathrm{Ni}-\mathrm{MH}$ batteries determined in $\mathrm{HNO}_{3}$ media. Taking into account the obtained distribution coefficients, it is evident that Diphonix resin exhibits strong affinity for REEs and $\mathrm{Fe}(\mathrm{III})$. In the case of remaining metal ions, lower values of the distribution coefficient were obtained. The highest $D$ value was obtained for $\mathrm{La}(\mathrm{III})$ and the lowest for Ni(II). This may indicate that La(III) ions are most strongly sorbed by Diphonix, while Ni(II) ions are the weakest sorbed. Based on the $D$ value, a series of metal ions affinity was determined for the Diphonix resin: $\mathrm{La}($ III $)>\mathrm{Pr}$ (III) $>\mathrm{Fe}$ (III) $>\mathrm{Nd}$ (III ) $>\mathrm{Ce}($ III $)>\mathrm{Cu}(\mathrm{II})>\mathrm{Zn}(\mathrm{II})>\mathrm{Co}(\mathrm{II})>\mathrm{Ni}(\mathrm{II})$.

\subsection{Desorption studies}

Desorption studies was also performed to evaluate the regeneration abilities of Diphonix resin. Nitric acid(V) in concentrations of $0.5,1$ and $2 \mathrm{M}$ was used as a desorbing agent. The higher the concentration of desorbing agent, the higher the efficiency of the desorption process. Despite that the resin adsorbed more effectively La(III) ions than $\mathrm{Ni(II)}$ ones (their adsorption efficiency was about $100 \%$ and $60 \%$, respectively) their desorption efficiency was changed. The maximum desorption efficiency of La(III) ions was about $50 \%$ while for $\mathrm{Ni}(\mathrm{II})$ ions was almost $90 \%$ using $2 \mathrm{M} \mathrm{HNO}_{3}$.

Diphonix with the biphosphonic and sulfonic functional groups can be considered as a polymer acting with the dualmechanism with hydrophilic cation exchange and specific functional groups. Therefore it can be easily regenerated using both $6 \mathrm{M} \mathrm{HCl}$ and mixture of $2 \mathrm{M} \mathrm{H}_{2} \mathrm{SO}_{4}, 5 \mathrm{~g} / \mathrm{L} \mathrm{Cu}(\mathrm{I})$ (applied as a catalyst) and $0.44 \mathrm{M} \mathrm{H}_{2} \mathrm{SO}_{3}$ solutions at $358 \mathrm{~K}$. For $6 \mathrm{M} \mathrm{HCl}$ the process can be as follows with $90 \%$ of Fe(III) elution efficiency (Alexandratos et al. 2000; Horwitz et al. 1997a, b):

Diphonix-Fe $\mathrm{Fe}^{3+}+\mathrm{H}^{+} \rightleftarrows \mathrm{Fe}^{3+}+2$ Diphonix- $\mathrm{H}^{+}$

For the latter conditions $64 \%$ of $\mathrm{Fe}(\mathrm{III})$ can be eluted.

2 Diphonix- $\mathrm{Fe}^{3+}+2 \mathrm{H}^{+} \rightleftarrows 2 \mathrm{Fe}^{3+}+2$ Diphonix- $\mathrm{H}^{+} \quad$ very slow

$2 \mathrm{Fe}^{3+}+2 \mathrm{Cu}^{+} \rightleftarrows 2 \mathrm{Fe}^{2+}+2 \mathrm{Cu}^{2+} \quad$ favourable

$2 \mathrm{Cu}^{2+}+\mathrm{H}_{2} \mathrm{SO}_{3}+\mathrm{H}_{2} \mathrm{O} \rightleftarrows 2 \mathrm{Cu}^{+}$

$+\mathrm{H}_{2} \mathrm{SO}_{4}+2 \mathrm{H}^{+} \quad$ favourable

$\mathrm{Fe}^{3+}$ exploited in Eq. 21 leads to the shift of Eq. 22 to the right and therefore the overall process can be described as follows: 


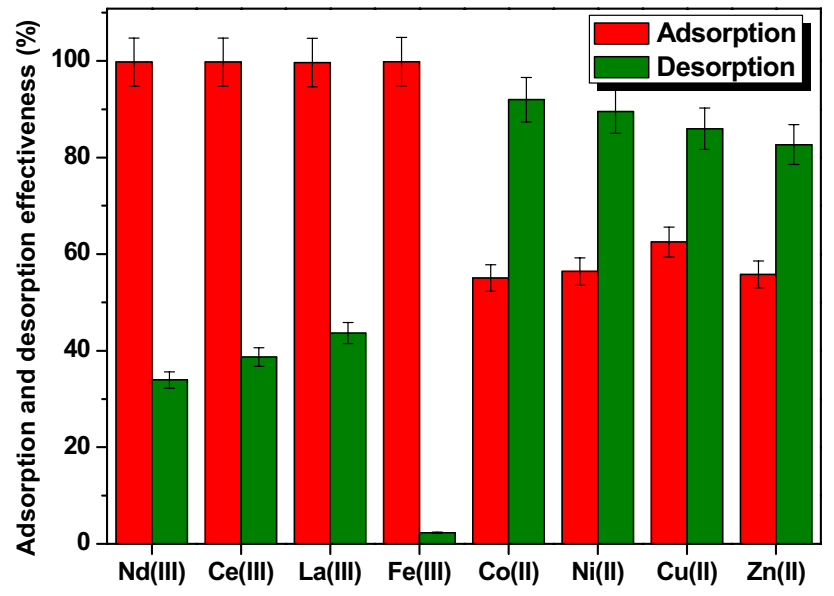

Fig. 9 Adsorption and desorption effectiveness of mixture metal ions on Diphonix resin

$$
\begin{aligned}
& \text { 2Diphonix-Fe } \mathrm{Fe}^{3+}+\mathrm{H}_{2} \mathrm{SO}_{3}+\mathrm{H}_{2} \mathrm{O} \rightleftarrows 2 \mathrm{Fe}^{2+} \\
& \quad+2 \text { Diphonix- } \mathrm{H}^{+}+\mathrm{H}_{2} \mathrm{SO}_{4}
\end{aligned}
$$

Almost $100 \%$ elution of $\mathrm{Fe}(\mathrm{III})$ can be achieved with the eluant with the excess of $1 \mathrm{~g} / \mathrm{L} \mathrm{Ti}(\mathrm{III})$ and $300 \mathrm{~g} / \mathrm{L}$ sulfuric acid at room temperature. Enhancement of the elution of iron with $\mathrm{Ti}(\mathrm{III})$ in the presence of $\mathrm{H}_{2} \mathrm{SO}_{4}$ can be attributed to reduction of $\mathrm{Fe}$ (III) and competitive adsorption of Ti(IV) (Lee and Nicol 2007).

\subsection{Metal ions mixture adsorption/desorption}

Effectiveness of the adsorption and desorption processes of metal ions mixture is illustrated in Fig. 9. As can be noticed metal ions adsorption in the + III oxidation state is much more efficient (about 100\%) than adsorption of metal ions in the + II oxidation state ( $60 \%$ effectiveness). In turn the desorption efficiency of metal ions in + III and + II oxidation states is about $40 \%$ and $90 \%$, respectively. Desorption of $\mathrm{Fe}$ (III) ions is negligible (about $2 \%$ ). It can be argued that $\mathrm{Fe}(\mathrm{III})$ ions are much more strongly adsorbed by the resin, not only on its surface but also in the resin pores. This information is confirmed by the manufacturer's data because the resin Diphonix is used for removal of Fe(III) ions. On the basis of the adsorption tests (the same initial metal ions concentrations), the series of selectivity of the Diphonix resin in relation to the studied metal ions was determined and presented as follows: $\mathrm{La}$ (III) $>\mathrm{Fe}$ (III) $>\mathrm{Nd}$ (III) $>\mathrm{Ce}$ (II I) $>\mathrm{Cu}($ II) $>\mathrm{Zn}$ (II) $>\mathrm{Co}$ (II) $>\mathrm{Ni}$ (II). This series is similar to the results obtained in the adsorption of metal ion mixtures with different initial concentrations.

\begin{tabular}{|c|c|c|c|c|c|}
\hline \multirow{2}{*}{$\begin{array}{l}\text { Material } \\
\text { Magnetic nanoparticles } \mathrm{CuFe}_{2} \mathrm{O}_{4}\end{array}$} & \multirow{2}{*}{$\begin{array}{l}\text { Optimal pH } \\
7-8\end{array}$} & \multicolumn{2}{|c|}{ Initial concentration $(\mathrm{mg} / \mathrm{L})$} & \multirow{2}{*}{$\begin{array}{l}\text { Adsorption } \\
\text { capacity } \\
(\mathrm{mg} / \mathrm{g})\end{array}$} & \multirow{2}{*}{$\begin{array}{l}\text { Refs. } \\
\text { Tu and Johnston (2018) }\end{array}$} \\
\hline & & $3-20$ & $\mathrm{La}, \mathrm{Ce}$ & & \\
\hline Calcium alginate & 5 & $50-200$ & $\mathrm{La}, \mathrm{Cu}$ & $\begin{array}{l}37.59(\mathrm{La}) \\
15.09(\mathrm{Cu})\end{array}$ & Kolodynska and Fila (2018) \\
\hline $\begin{array}{l}\text { Cyanex } 272 \text { impregnated } \\
\text { Amberlite XAD-7 resin }\end{array}$ & 2.5 & $\begin{array}{l}751(\mathrm{La}) \\
113(\mathrm{Nd})\end{array}$ & $\mathrm{La}, \mathrm{Nd}$ & $\begin{array}{l}11.1(\mathrm{La}) \\
1.69(\mathrm{Nd})\end{array}$ & İnan et al. (2018) \\
\hline Synthetic alumosilicate zeolite & - & - & $\mathrm{Ni}, \mathrm{Cu}, \mathrm{Fe}$ & $\begin{array}{l}140(\mathrm{Ni}) \\
160(\mathrm{Cu}) \\
560(\mathrm{Fe})\end{array}$ & Shilina et al. (2017) \\
\hline $\begin{array}{l}\text { Oxidized ordered mesoporous } \\
\text { carbons }\end{array}$ & 5 & - & $\mathrm{Ni}, \mathrm{Co}$ & $\begin{array}{l}126-145(\mathrm{Ni}) \\
135-148(\mathrm{Co})\end{array}$ & Marciniak et al. (2018) \\
\hline $\begin{array}{l}\text { Chelating resin } \\
\text { 1,8-(3,6-dithiaoctyl)-4-polyvi- } \\
\text { nylbenzenesuphonate (dpvbs) }\end{array}$ & $\begin{array}{l}5.5 \\
6\end{array}$ & 150 & $\begin{array}{l}\mathrm{Cu} \\
\mathrm{Fe}, \mathrm{Co}, \mathrm{Ni}\end{array}$ & $\begin{array}{l}46.07(\mathrm{Cu}) \\
44.68(\mathrm{Fe}) \\
30.94(\mathrm{Co}) \\
28.47(\mathrm{Ni})\end{array}$ & Khalil et al. (2018) \\
\hline \multirow[t]{2}{*}{ Diphonix resin } & 2 & $25-600$ & $\mathrm{La}, \mathrm{Ni}$ & $\begin{array}{l}59.41(\mathrm{La}) \\
26.69(\mathrm{Ni})\end{array}$ & This study \\
\hline & & $\begin{array}{l}4.55(\mathrm{Nd}) \\
6.45(\mathrm{Ce}) \\
35.6(\mathrm{La}) \\
58.75(\mathrm{Fe}) \\
16.30(\mathrm{Co}) \\
134.40(\mathrm{Ni}) \\
4.7(\mathrm{Cu}) \\
4.5(\mathrm{Zn})\end{array}$ & $\mathrm{Nd}, \mathrm{Ce}, \mathrm{La}, \mathrm{Fe}, \mathrm{Co}, \mathrm{Ni}, \mathrm{Cu}, \mathrm{Zn}$ & $\begin{array}{l}0.65(\mathrm{Nd}) \\
1.00(\mathrm{Ce}) \\
6.65(\mathrm{La}) \\
3.48(\mathrm{Fe}) \\
1.74(\mathrm{Co}) \\
14.86(\mathrm{Ni}) \\
0.15(\mathrm{Cu}) \\
0.41(\mathrm{Zn})\end{array}$ & \\
\hline
\end{tabular}

Table 6 Adsorption capacity of REEs and HMs for various materials 


\subsection{Comparison of adsorption capacity of REEs and HMs with various materials}

The adsorption capacity of the Diphonix resin for the recovery of $\mathrm{La}$ (III), $\mathrm{Ce}(\mathrm{III}), \mathrm{Nd}(\mathrm{III}), \mathrm{Fe}(\mathrm{III}), \mathrm{Ni}$ (II), $\mathrm{Co}(\mathrm{II})$, $\mathrm{Cu}$ (II) and $\mathrm{Zn}$ (II) was compared with that of various materials reported in the literature and the obtained results are included in Table 6. They indicate that the Diphonix resin is characterized by good adsorption properties. Compared to various materials, Diphonix adsorbs efficiently both rare earth and heavy metals when $\mathrm{pH}$ is equal to 2, implying that this resin has a great potential in recovery of REEs and HMs even in strongly acidic solutions. Additionally, Diphonix has the highest adsorption capacity for $\mathrm{La}(\mathrm{III})$ ions $(59.41 \mathrm{mg} / \mathrm{g}$ ) in comparison to the other listed materials, such as magnetic nanoparticles $\mathrm{CuFe}_{2} \mathrm{O}_{4}(42.02 \mathrm{mg} / \mathrm{g})$, calcium alginate $(37.59 \mathrm{mg} / \mathrm{g}$ ) and Cyanex 272 impregnated Amberlite XAD-7 resin $(11.1 \mathrm{mg} / \mathrm{g})$. Thus, this material is a promising adsorbent for recovery of rare earth and heavy metals from different solutions.

\section{Conclusions}

In this paper Diphonix resin was chosen for adsorption studies responsible for the multifunctional and twofold nature of metal ions binding with its surface due to the presence of three functional groups in its structure. The acid diphosphate groups present in the resin are specific for many metal ions and play an important role in the adsorption process. Due to the extraordinary coordination properties of the phosphonic group, it is possible to form high-stability metal complexes even under strongly acidic conditions. The Diphonix resin provides unique exchange kinetics because the hydrophilic groups of sulfonic acid allow quick access of metal ions to selective diphosphonic groups in the polymer matrix. The Diphonix was characterized by very good adsorption capacity in the nitric acid especially in $0.2 \mathrm{M} \mathrm{HNO}_{3}$ media. In the case of single $\mathrm{Ni}(\mathrm{II})$ and $\mathrm{La}(\mathrm{III})$ ions the equilibrium of the adsorption process was achieved rapidly which indicates a high affinity of the adsorbed ions for the resin. Adsorption equilibrium state was obtained after about $10 \mathrm{~min}$. Satisfactory results were achieved in the whole range of concentrations. Preliminary studies of metal ions mixture adsorption turned out to be equally effective. Particularly good results with rare earth ions were obtained. It was found that the Diphonix can be an effective material for recovery and separation of the rare earth elements and strategic metal ions contained in the solutions after $\mathrm{Ni}-\mathrm{MH}$ cells leaching where the leaching agent is nitric acid. However, based on the study results, it was found that $\mathrm{Fe}(\mathrm{III})$ ions also adsorbed with high efficiency which could make further research using real solutions difficult. The first step in this case could be to eliminate the interfering factors by their precipitation, sediment analysis and then a series of activities associated with the recovery and separation of other components. Studies using the real solutions after Ni-MH leaching and the Diphonix resin are planned in further.

Acknowledgements The authors are grateful for Mgr Malwina Majdańska help during the research. We also acknowledge the financial support from the National Centre of Research and Development within Project Proposal No. POIR.04.01.01-00-0040/17.

Open Access This article is distributed under the terms of the Creative Commons Attribution 4.0 International License (http://creativeco mmons.org/licenses/by/4.0/), which permits unrestricted use, distribution, and reproduction in any medium, provided you give appropriate credit to the original author(s) and the source, provide a link to the Creative Commons license, and indicate if changes were made.

\section{References}

Abderrahim, O., Didi, M.A., Moreau, B., Villemin, D.: A new sorbent for selective separation of metal: polyethylenimine methylenephosphonic acid. Solvent Extr. Ion Exch. 24, 943-955 (2006). https://doi.org/10.1080/07366290600952519

Alexandratos, S.D.: New polymer-supported ion-complexing agents: design, preparation and metal ion affinities of immobilized ligands. J. Hazard. Mater. 139, 467-470 (2007). https://doi. org/10.1016/j.jhazmat.2006.02.042

Alexandratos, S.D., Zhu, X.: ATR-FTIR spectroscopy as a probe for metal ion binding onto immobilized ligands. Mater. Chem. Phys. 218, 196-203 (2018). https://doi.org/10.1016/j.matchemphy s.2018.07.026

Alexandratos, S.D., Shelley, C.A., Horwitz, E.P., Chiarizia, R., Gula, M.J., Sui, X.: Bifunctional phenyl monophosphonic/sulfonic acid ion exchange resin and process for using the same, Patent WO2000001458A1 (2000)

Ali, R.M., Hamad, H.A., Hussein, M.M., Malash, G.F.: Potential of using green adsorbent of heavy metal removal from aqueous solutions: adsorption kinetics, isotherm, thermodynamic, mechanism and economic analysis. Ecol. Eng. 91, 317-332 (2016). https:// doi.org/10.1016/j.ecoleng.2016.03.015

Arthy, M., Saravanakumar, M.P.: Isotherm modeling, kinetic study and optimization of batch parameters for effective removal of Acid Blue 45 using tannery waste. J. Mol. Liq. 187, 189-200 (2013). https://doi.org/10.1016/j.molliq.2013.06.019

Babaeivelni, K., Khodadoust, A.P., Bogdan, D.: Adsorption and removal of arsenic(V) using crystalline manganese (II,III) oxide: kinetics, equilibrium, effect of $\mathrm{pH}$ and ionic strength. J. Environ. Sci. Health. A. 49, 1462-1473 (2014). https://doi. org/10.1080/10934529.2014.937160

Bentiss, F., Lebrini, M., Lagrenée, M.: Thermodynamic characterization of metal dissolution and inhibitor adsorption processes in mild steel/2,5-bis(n-thienyl)-1,3,4-thiadiazoles/ hydrochloric acid system. Corros. Sci. 47, 2915-2931 (2005). https://doi. org/10.1016/j.corsci.2005.05.034

Bertuol, D.A., Bernardes, A.M., Tenório, J.A.S.: Spent NiMH batteries: characterization and metal recovery through mechanical processing. J. Power Sources. 160, 1465-1470 (2006). https://doi. org/10.1016/j.jpowsour.2006.02.091 
Bertuol, D.A., Bernardes, A.M., Tenório, J.A.S.: Spent NiMH batteries: the role of selective precipitation in the recovery of valuable metals. J. Power Sources 193, 914-923 (2009)

Chakhmouradian, A.R., Wall, F.: Rare earth elements: minerals, mines, magnets (and more). Elements. 8, 333-340 (2012). https://doi. org/10.2113/gselements.8.5.333

Chiariza, R., Horwitz, E.P., Alexandrators, S.D., Gula, M.J.: Diphonix® Resin: a review of its properties and applications. Sep. Sci. Technol. 32, 1-35 (1997)

Chiarizia, R., Horwitz, E.P., Alexandratos, S.D.: Uptake of metal ions by a new chelating ion-exchange resin. Part 4: kinetics. Solvent Extr. Ion Exch 12, 211-237 (1994)

Chiarizia, R., Ferraro, J.R., Horwitz, E.P., D’Arcy, K.A.: Uptake of metal ions by a new chelating ion-exchange resin. VII. Alkaline Earth Cations. Solvent Extr. Ion Exch. 13, 1063-1082 (1995)

Ekberg, C., Petranikova, M.: Chap. 7-Lithium Batteries Recycling. Elsevier Inc., Amsterdam (2015)

Gula, M.J., Dreisinger, D.B.: The ion exchange control of iron in copper electrolyte stream using Eichrom's Diphonix resin. In: SME Annual Meeting, Phoenix, 11-14 March: (1996)

Hajiev, S.N., Kertman, S.V., Leykin, U.A., Amelin, A.N.: Thermochemical study of ion echange processess. V. Sorption of copper ions in complex-forming resins. Thermochim. Acta 139, 327-332 (1989)

Horwitz, E.P., Chiarizia, R., Diamond, H., Gatrone, R.C., Alexandratos, S.D., Trochimczuk, A.Q., Crick, D.W.: Uptake of metal ions by a new chelating ion-exchange resin: Part 1: Acid dependencies of actinide ions. Solvent Extr. Ion Exch. 11, 943-966 (1993)

Horwitz, E.P., Chiarizia, R., Alexandratos, D.S., Gula, M.: Recent advances in the chemistry and applications of the diphonix resins. ACS Symp. Ser. 716, 206-218: (1997a). https://doi.org/10.1021/ bk-1999-0716.ch014

Horwitz, E.P., Chiarizia, R., Dietz, M.L.: DIPEX: a new extraction chromatographic material for the separation and preconcentration of actinides from aqueous solution. React. Funct. Polym. 33, 25-36 (1997b). https://doi.org/10.1016/S1381-5148(97)00013-8 b

İnan, S., Tel, H., Sert, S., Çetinkaya, B., Sengül, S., Özkan, B., Altaş, Y.: Extraction and separation studies of rare earth elements using Cyanex 272 impregnated Amberlite XAD-7 resin. Hydrometallurgy. 181, 156-163 (2018). https://doi.org/10.1016/j.hydro met.2018.09.005

Innocenzi, V., Ippolito, N.M., De Michelis, I., Prisciandaro, M., Medici, F., Vegliò, F.: A review of the processes and lab-scale techniques for the treatment of spent rechargeable NiMH batteries. J. Power Sources. 362, 202-218 (2017). https://doi.org/10.1016/j. jpowsour.2017.07.034

Issaadi, S., Douadi, T., Zouaoui, A., Chafaa, S., Khan, M.A., Bouet, G.: Novel thiophene symmetrical Schiff base compounds as corrosion inhibitor for mild steel in acidic media. Corros. Sci. 53, 1484-1488 (2011). https://doi.org/10.1016/j.corsci.2011.01.022

Jha, M.K., Kumari, A., Panda, R., Kumar, J. R., Yoo, K., Lee, J. Y.: Review on hydrometallurgical recovery of rare earth metals. Hydrometallurgy 165, 2-26 (2016)

Khalil, T.E., El-Dissouky, A., Rizk, S.: Equilibrium and kinetic studies on $\mathrm{Pb}^{2+}, \mathrm{Cd}^{2+}, \mathrm{Cu}^{2+}$ and $\mathrm{Ni}^{2+}$ adsorption from aqueous solution by resin $2,2^{\prime}$-(ethylenedithio)diethanol immobilized amberlite XAD-16 (EDTDE-AXAD-16) with chlorosulphonic acid. J. Mol. Liq. 219, 533-546 (2016). https://doi.org/10.1016/j.molli q.2016.03.063

Khalil, T.E., Elbadawy, H.A., El-Dissouky, A.: Synthesis, characterization and physicochemical studies of new chelating resin 1 , 8-(3, 6-dithiaoctyl)-4-polyvinylbenzenesulphonate (dpvbs) and its metallopolymer $\mathrm{Cu}(\mathrm{II}), \mathrm{Ni}(\mathrm{II}), \mathrm{Co}(\mathrm{II})$ and $\mathrm{Fe}(\mathrm{III})$ complexes. J. Mol. Struct. 1154, 100-113 (2018). https://doi.org/10.1016/j. molstruc.2017.10.033
Kiruba, U.P., Kumar, P.S., Prabhakaran, C., Aditya, V.: Characteristics of thermodynamic, isotherm, kinetic, mechanism and design equations for the analysis of adsorption in $\mathrm{Cd}(\mathrm{II})$ ions-surface modified Eucalyptus seeds system. J. Taiwan Inst. Chem. Eng. 45, 2957-2968 (2014)

Kolodynska, D., Fila, D.: Lanthanides and heavy metals sorption on alginates as effective sorption materials. Desalin. Water Treat. 131, 238-251 (2018). https://doi.org/10.5004/dwt.2018.23020

Kołodyńska, D.: Diphonix resin ${ }^{\circledR}$ in sorption of heavy metal ions in the presence of the biodegradable complexing agents of a new generation. Chem. Eng. J. 159, 27-36 (2010). https://doi.org/10.1016/j. cej.2010.02.017

Konicki, W., Aleksandrzak, M., Mijowska, E.: Equilibrium, kinetic and thermodynamic studies on adsorption of cationic dyes from aqueous solutions using graphene oxide. Chem. Eng. Res. Des. 123, 35-49 (2017). https://doi.org/10.1016/j.cherd.2017.03.036

Kwo-Hsiung, Y.: Research in nickel/metal hydride batteries 2016. Batteries 2, 31 (2016). https://doi.org/10.3390/batteries2040031

Kwo-Hsiung, Y., Ouchi, T., Nei, J., Moghe, D.: The importance of rareearth additions in $\mathrm{Zr}$-based $\mathrm{AB}_{2}$ metal hydride alloys. Batteries $\mathbf{2}$, 25 (2016). https://doi.org/10.3390/batteries2030025

Lazar, L., Bandrabur, B., Tataru-Fărmuş, R., Drobot, M., Bulgariu, L., Gutt, G.: FTIR analysis of ion exchange resins with application. Environ. Eng. Manag. J. 13, 2145-2152 (2014)

Lee, M.S., Nicol, M.J.: Removal of iron from cobalt sulfate solutions by ion exchange with Diphonix resin and enhancement of iron elution with titanium(III). Hydrometallurgy. 86, 6-12 (2007). https ://doi.org/10.1016/j.hydromet.2006.10.002

Lucas, J., Lucas, P., Le Mercier, T., Rollat, A., Davenport, W.: Chapter 10-Rare earths in rechargeable batteries. Rare Earths (2015). https://doi.org/10.1016/B978-0-444-62735-3.00010-3

Marciniak, M., Goscianska, J., Frankowski, M., Pietrzak, R.: Optimal synthesis of oxidized mesoporous carbons for the adsorption of heavy metal ions. J. Mol. Liq. 276, 630-637 (2018). https://doi. org/10.1016/j.molliq.2018.12.042

Maxwell, I.I.I., Bernard, S.L., Nelson, M.A., Youmans, M.R.: L.D.: New method for removal of spectral interferences for beryllium assay using inductively coupled plasma atomic emission spectrometry. Talanta. 76, 432-440 (2008). https://doi.org/10.1016/j. talanta.2008.03.032

McKevitt, B., Dreisinger, D.: A comparison of various ion exchange resins for the removal of ferric ions from copper electrowinning electrolyte solutions Part II: electrolytes containing antimony and bismuth. Hydrometallurgy 98, 122-127 (2009)

Meshram, P., Pandey, B.D., Mankhand, T.R.: Leaching of base metals from spent $\mathrm{Ni}$-metal hydride batteries with emphasis on kinetics and characterization. Hydrometallurgy. 158, 172-179 (2015). https://doi.org/10.1016/j.hydromet.2015.10.028

Meshram, P., Pandey, B.D., Mankhand, T.R.: Process optimization and kinetics for leaching of rare earth metals from the spent Ni-metal hydride batteries. Waste Manag 51, 196-203 (2016)

Meshram, P., Somani, H., Dhar, B., Raj, T., Deveci, H.: Two stage leaching process for selective metal extraction from spent nickel metal hydride batteries. J. Clean. Prod. 157, 322-332 (2017). https ://doi.org/10.1016/j.jclepro.2017.04.144

Müller, T., Friedrich, B.: Development of a recycling process for nickel-metal hydride batteries. J. Power Sources 158, 1498-1509 (2006)

Nash, K.L., Rickert, P.G., Muntean, J.V., Alexandratos, S.D.: Uptake of metal ions by a new chelating ion exchange resin. Part 3: protonation constants via potentiometric titration and solid state ${ }^{31} \mathrm{P}$ NMR spectroscopy. Solvent Extr. Ion Exch. 12, 192-204 (1994)

Nekrasova, N.A., Gelis, V.M., Milyutin, V.V., Budantseva, N.A., Kozlitin, E.A., Logunov, M.V., Pristinskii, Y.E.: Sorption of Th, U, and Am on phosphorus-containing ion-exchange materials. Radiochemistry 52, 71-75 (2010) 
Phillips, D.H., Gu, B., Watson, D.B., Parmele, C.S.: Uranium removal from contaminated groundwater by synthetic resins. Water Res. 42, 260-268 (2008). https://doi.org/10.1016/j.watres.2007.07.010

Pietrelli, L., Bellomo, B., Fontana, D., Montereali, M.R.: Rare earths recovery from NiMH spent batteries. Hydrometallurgy. 66, 135139 (2002). https://doi.org/10.1016/S0304-386X(02)00107-X

Pietrelli, L., Bellomo, B., Fontana, D., Montereali, M.: Characterization and leaching of NiCd and NiMH spent batteries for the recovery of metals. Waste Manag. 25, 221-226 (2005). https:// doi.org/10.1016/j.wasman.2004.12.013

Reguyal, F., Sarmah, A.K., Gao, W.: Synthesis of magnetic biochar from pine sawdust via oxidative hydrolysis of $\mathrm{FeCl}_{2}$ for the removal sulfamethoxazole from aqueous solution. J. Hazard. Mater. 321, 868-878 (2016). https://doi.org/10.1016/j.jhazm at.2016.10.006

Rodrigues, L.E.O.C., Mansur, M.B.: Hydrometallurgical separation of rare earth elements, cobalt and nickel from spent nickel-metalhydride batteries. J. Power Sources 195, 3735-3741 (2010)

Santos, V.E.O., Celante, V.G., Lelis, M.F.F., Freitas, M.B.J.G.: Chemical and electrochemical recycling of the nickel, cobalt, zinc and manganese from the positives electrodes of spent $\mathrm{Ni}-\mathrm{MH}$ batteries from mobile phones. J. Power Sources. 218, 435-444 (2012). https ://doi.org/10.1016/j.jpowsour.2012.07.024

Shaw, D.R., Dreisinger, D.B., Lancaster, T., Richmond, G.D., Tomlinson, M.: The commercialization of the FENIX iron control system for purifying copper electrowinning electrolytes. J. Met. 56, 38-41 (2004). https://doi.org/10.1007/s11837-004-0090-x

Shengqiang, Z., Xiuyang, H., Dahui, W.: Review on comprehensive recovery of valuable metals from spent electrode materials of nickel-hydrogen batteries. Rare Met. Mater. Eng. 44, 73-78 (2015). https://doi.org/10.1016/S1875-5372(15)30015-1

Shilina, A.S., Bakhtin, V.D., Burukhin, S.B., Askhadullin, S.R.: Sorption of cations of heavy metals and radionuclides from the aqueous media by new synthetic zeolite-like sorbent. Nucl. Energy Technol. 0, 1-6 (2017). https://doi.org/10.1016/j.nucet .2017.10.001

Singare, P.U.: Thermal degradation studies of some strongly acidic cation exchange resins. Open J. Phys. Chem. 1, 45-54 (2011)
Skowroński, J.M., Rozmanowski, T., Osińska, M.: Reuse of nickel recovered from spent $\mathrm{Ni}-\mathrm{Cd}$ batteries for the preparation of $\mathrm{C} /$ $\mathrm{Ni}$ and $\mathrm{C} / \mathrm{Ni} / \mathrm{Pd}$ layered electrodes for energy sources. Process Saf. Environ. Prot. 93, 139-146 (2015). https://doi.org/10.1016/j. psep.2014.02.007

Smolik, M., Jakóbik-Kolon, A., Porański, M.: Separation of zirconium and hafnium using Diphonix ${ }^{\circledR}$ chelating ion-exchange resin. Hydrometallurgy. 95, 350-353 (2009). https://doi.org/10.1016/j. hydromet.2008.05.010

Tarabay, J., Karami, N.: Nickel Metal Hydride battery: Structure, chemical reaction, and circuit model. In: 3rd International Conference on Technological Advances in Electrical, Electronics and Computer Engineering, TAEECE 2015. pp. 22-26 (2015)

$\mathrm{Tu}$, Y.J., Johnston, C.T.: Rapid recovery of rare earth elements in industrial wastewater by $\mathrm{CuFe}_{2} \mathrm{O}_{4}$ synthesized from $\mathrm{Cu}$ sludge. J. Rare Earths. 36, 513-520 (2018). https://doi.org/10.1016/j. jre.2017.11.009

Viegas, R.M.C., Campinas, M., Costa, H., Rosa, M.J.: How do the HSDM and Boyd's model compare for estimating intraparticle diffusion coefficients in adsorption processes. Adsorption 20, 737-746 (2014)

Wang, J., Chen, M., Chen, H., Luo, T., Xu, Z.: Leaching study of spent Li-ion Batteries. Procedia Environ. Sci. 16, 443-450 (2012). https ://doi.org/10.1016/j.proenv.2012.10.061

Xue, S.S., Harvey, J., Gula, M.J., Horwitz, E.P.: Control of iron in copper electrolyte streams with a new monophosphonic/sulphonic acid resin. Miner. Metall. Process. 18, 133-137 (2001)

Yantasee, W., Fryxell, G.E., Addleman, R.S., Wiacek, R.J., Koonsiripaiboon, V., Pattamakomsan, K., Sukwarotwat, V., Xu, J., Raymond, K.N.: Selective removal of lanthanides from natural waters, acidic streams and dialysate. J. Hazard. Mater. 168, 1233-1238 (2009)

Young, K.-H.: Research in nickel/metal hydride batteries 2016. Batteries 2(4), 31 (2016). https://doi.org/10.3390/batteries2040031

Yuanfeng, W., Lei, Z., Jianwei, M., Shiwang, L., Jun, H., Yuru, Y., Lehe, M.: Kinetic and thermodynamic studies of sulforaphane adsorption on macroporous resin. J. Chromatogr. B. 1028, 231236 (2016)

\section{Affiliations}

\section{Fila ${ }^{1}$ Z. Hubicki ${ }^{1} \cdot$ D. Kołodyńska ${ }^{1}$}

D. Fila

dominika.fila@poczta.umcs.lublin.pl
1 Department of Inorganic Chemistry, Faculty of Chemistry, Maria Curie-Sklodowska University, M. Curie Sklodowska Sq. 2, 20-031 Lublin, Poland 